\title{
TESTING METHODS FOR MECHANICALLY TREATED SOILS: RELIABILITY AND VALIDITY
}

\author{
Ana PetkovšeK*, Matej MaČek, Jasna Smolar \\ University of Ljubljana, Faculty of Civil and Geodetic Engineering, Jamova 2, Ljubljana, Slovenia \\ * corresponding author: ana.petkovsek@fgg.uni-lj.si
}

\begin{abstract}
.
A possibility of in-situ mechanical improvement for reducing the liquefaction potential of silty sands was investigated by using three different techniques: Vibratory Roller Compaction, Rapid Impact Compaction (RIC) and Soil Mixing. Material properties at all test sites were investigated before and after improvement with the laboratory and the in situ tests (CPT, SDMT, DPSH B, static and dynamic load plate test, geohydraulic tests). Correlation between the results obtained by different test methods gave inconclusive answers.
\end{abstract}

KEYwords: Liquefaction, Experimental Site, Rapid Impact Compaction, Soil Mixing.

\section{INTRODUCTION}

The term ground improvement refers to any technique or process that improves the engineering properties of the treated soil mass in order to fulfil the purpose intended. Usually, the modified properties are strength, stiffness, permeability, workability (willingness for compaction), resistance to frost, etc. [1] 4. The type of ground improvement/soil treatment depends on the demands of the structure to be built, the soil type, the available materials and tools, and the local tradition and experience.

The efficiency of a specific improvement technique may be measured by using different testings and instrumentation. Whenever a laboratory or field test/measuring device is used as part of the data collection process, the validity and the reliability of the test/device is important. Just as we would not use a test for the determination of particle size distribution to assess the activity of clay, we would not want to use any measuring device not capable of measuring properties which are of the design or QA - QC interest.

This paper focuses on the validity and sensitivity of the laboratory and field tests used to assess the efficiency of the mechanical improvement of siltysandy soils. Special attention is given to the use of Kozeny-Carman equation for the estimation of the soil permeability.

Analysis presented in the paper refers to the investigation performed at the location of Hydropower plant (HPP) Brežice, SE Slovenia, where the top layer of the foundation ground indicates properties of liquefiable soil. The main goal of the ground improvement is to increase the soil liquefaction resistance and to assure the required permeability of the fill material to be used for app. $14 \mathrm{~km}$ long dikes along the HPP reservoir.

\section{BACKGROUND}

\subsection{Site DESCRIPTION}

The reservoir of the HPP Brežice requires the construction of app. $7 \mathrm{~km}$ long and up to $10 \mathrm{~m}$ high dikes on both sides of the river Sava. The top layer of the foundation ground consists of loose silty sands, prone to liquefaction.

HPP Brežice is the $5^{\text {th }}$ in the chain of the lower Sava river HPPs (Figure 1) and is situated in the influential area of Nucler Power plant Krško (NPP).

Tectonically, the wider area belongs to the tectonic unit named "Krško basin", which is considered a potentially active structure [5. A well-documented earthquake with a magnitude of 5.7 and intensity of VIII EMS occurred in January 1917 6].

The so called "Zagreb earthquake" in 1880 triggered liquefaction along the river bank between Brežice and Zagreb (Croatia) [7, 8]. The design ground accelerations in the Krško basin for different earthquake return periods are presented in Table 1 .

\subsection{Geological profile}

The geological profile is quite uniform over the entire area of the HPP (Figure 2). The top layer is up to $5 \mathrm{~m}$ thick, made of very loose sandy silts and sands (ML, SM, SP), deposited by recent floods. The top soil layer contains fine coal particles that origin from the flotation processes from the area around $60 \mathrm{~km}$ upstream where the coal mines have operated for the last 300 years. Coal particles confirm the very young origin of the sediments. Poplar tree roots appear up to $4 \mathrm{~m}$ deep and also prove the development of the "paleo" ground between the larger flood events.

Beneath the top layer the medium dense to dense Quaternary gravels are deposited. The gravel is classified as silty sandy gravel (GM) to poorly graded gravel (GP) and consists mainly of limestone grains. 


\begin{tabular}{llllll}
\hline $\begin{array}{l}\text { Return } \\
\text { period }\end{array}$ & $\begin{array}{l}\text { Magnitude } \\
\text { (determined } \\
\text { with } \\
\text { probabilistic } \\
\text { analysis) }\end{array}$ & $\begin{array}{l}\text { Magnitude } \\
\text { scaling factor } \\
\text { (MSF) }\end{array}$ & $\begin{array}{l}\text { Design ground } \\
\text { acceleration in } \\
\text { rock }\end{array}$ & $\begin{array}{l}\text { Ground acceleration in } \\
\text { Krško basin } \\
\text { (determined with } \\
\text { probabilistic analysis) }\end{array}$ \\
\hline Years & & & & In rock & In sand \\
\hline 200 & 5.6 & 1.64 & & $0.230 \mathrm{~g}$ & $0.290 \mathrm{~g}$ \\
475 & 5.8 & 1.56 & $0.225 \mathrm{~g}$ & $0.280 \mathrm{~g}$ & $0.350 \mathrm{~g}$ \\
1000 & 6.25 & 1.39 & $0.250 \mathrm{~g}$ & $0.295 \mathrm{~g}$ & $0.370 \mathrm{~g}$ \\
\hline
\end{tabular}

TABLE 1. Design ground accelerations for different earthquake return periods $9-11]$

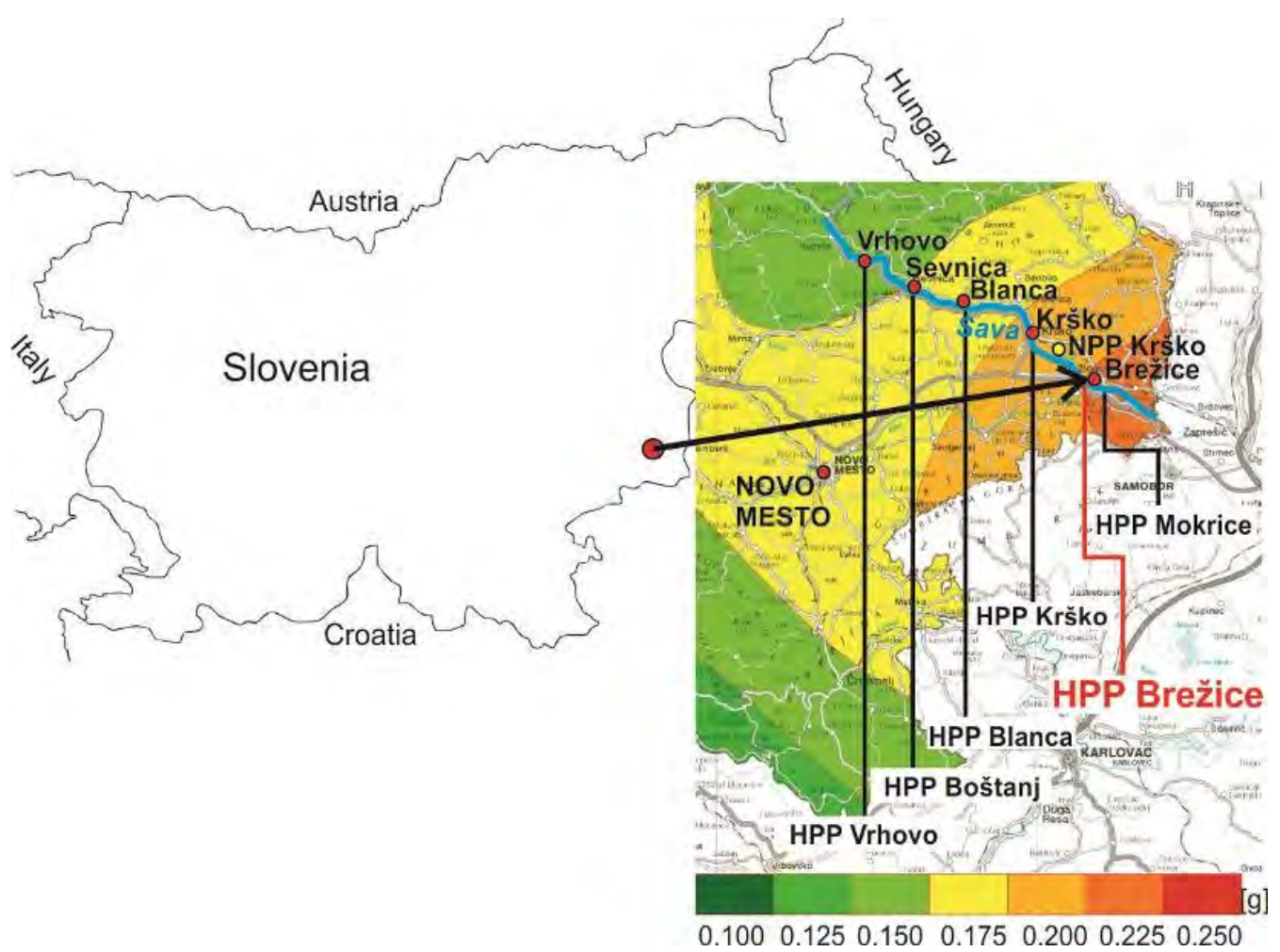

FiguRe 1. Location of the HPP Brežice.

The thickness of gravel deposits varies between 8 and $12 \mathrm{~m}$.

The pre-quaternary bedrock below the gravel consist of Miocene sediments, represented by overconsolidated, not cemented silts and marls, with some inclusions of the weak, soft limestones.

The ground water (GW) level is controlled by the Sava River. During most of the year, the GW level appears app. 4-6 m below the ground surface, inside the gravel layer. During the floods, the GW may rise up to $2 \mathrm{~m}$ above the ground and may stay there for days.

When the HPP Brežice is put into operation, the existing ground surface and silty/sandy layers will be permanently flooded in the area between the dikes on the left and the right river bank. The permanent rise of the GW level is forecast also at the influential area from Brežice to Krško, on the dry sides of the dikes.

\subsection{SOIL PROPERTIES}

\subsubsection{INDEX PROPERTIES}

The grain size distribution of the Quaternary soils is not uniform. In the top layer they may vary from sandy silt to poorly graded sand (Figure 3). According to empirical data [12, 13, the top layer soils belong to the groups of most liquefiable and potentially liquefiable soils. Index properties of typical soils from the top layer are given in Table 2 .

Laboratory Proctor compaction tests show that due to the presence of coal particles, unfavourable grading and uneven water content distribution, the top layer soils willingness to compaction is poor. Different compaction curves (Figure 4 confirm heterogeneity of different strata, deposited inside the top layer.

\subsubsection{LIQUEFACTION POTENTIAL}

The SPT testsperformed in top soil layer shown the modified blow count $\left(N_{1}\right)_{60}$ between 2 and 8 . Seed and Idriss 14 proposed an empirical method for assessing 

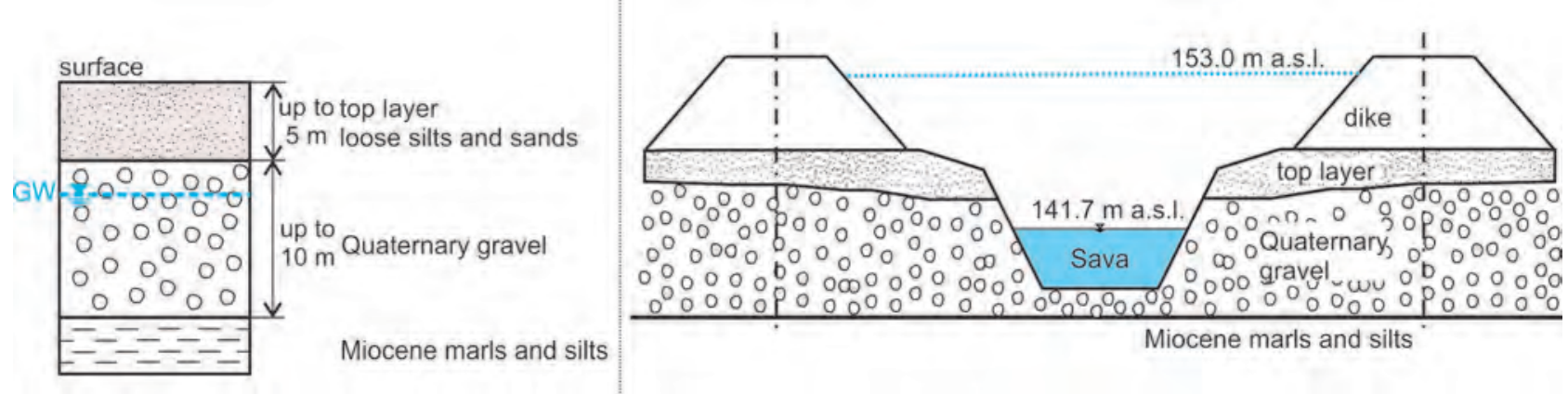

Figure 2. Schematic geological profile (left) and schematic cross section of the valley after the HPP construction (right). Not in scale.

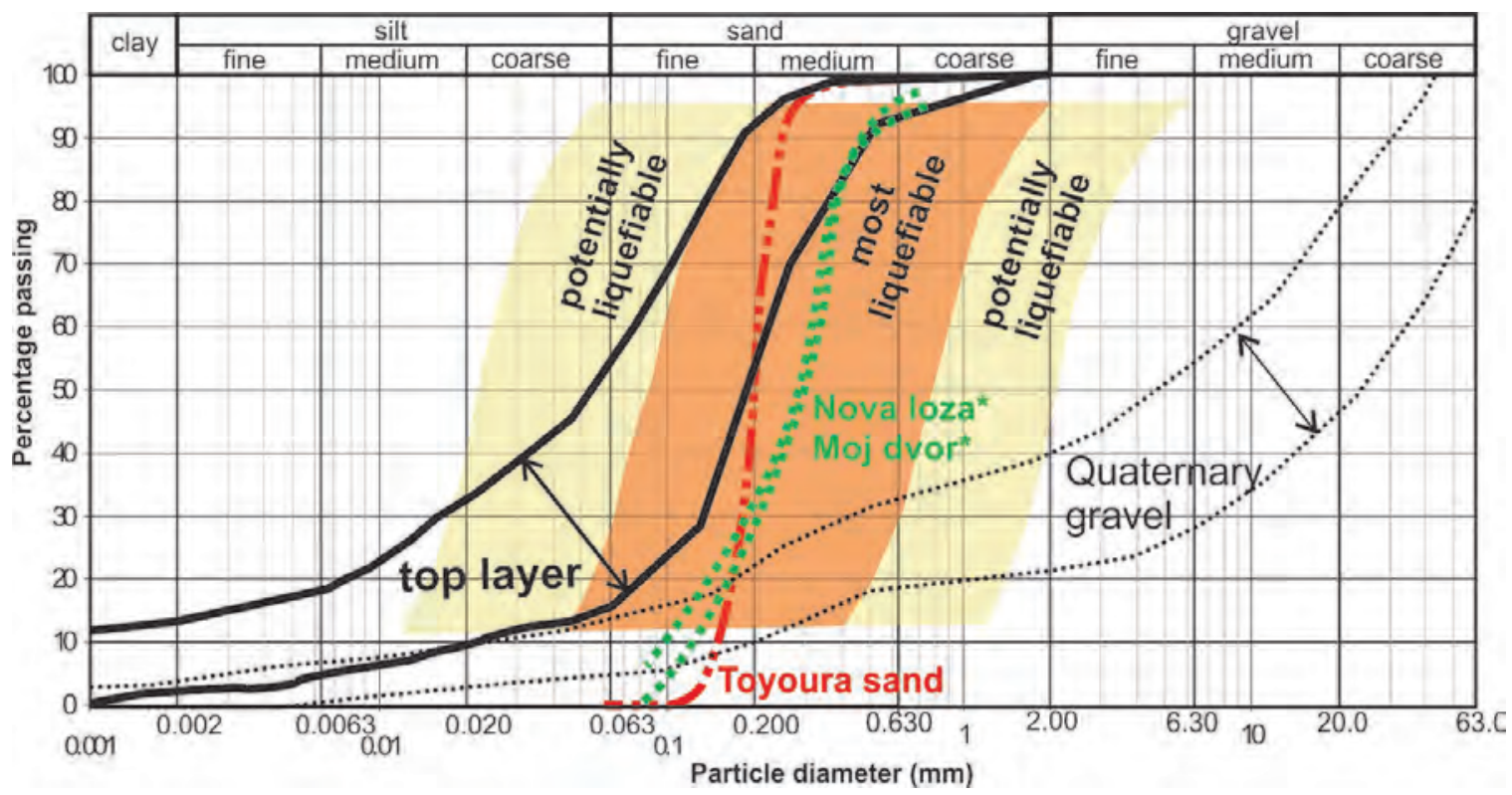

FIGURE 3. Relationship between grading and liquefaction potential [13, with the boundaries of the grading of top layer and quaternary gravel at the HPP Brežice. Grading curves *Nova Loza and *Moj dvor, reported by Veinović et al. [7] belong to the area, where liquefaction appeared in 1880 .

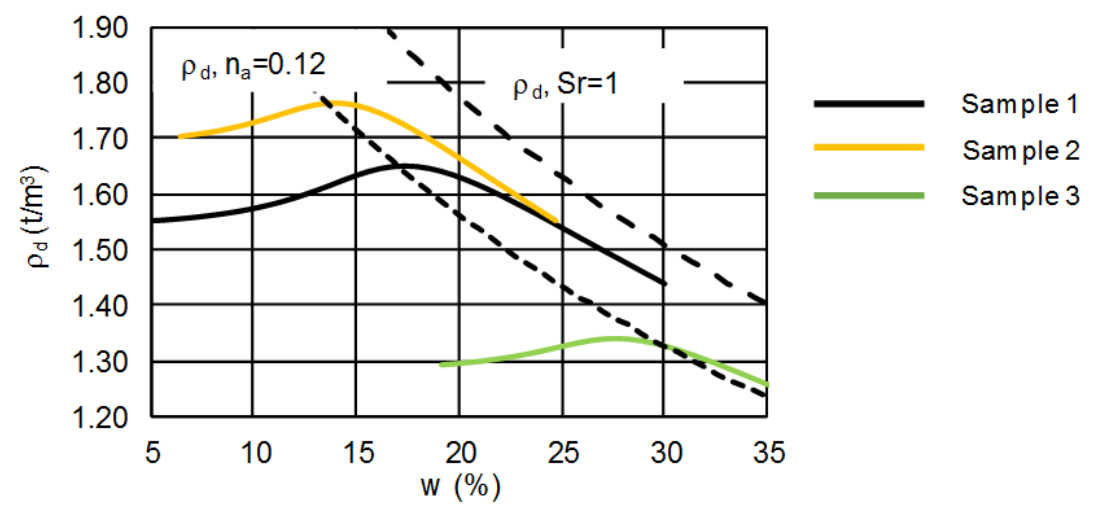

FIgURE 4. Proctor curves for three typical groups of soils from the top layer. 


\begin{tabular}{|c|c|c|c|}
\hline Sample & 1 & 2 & 3 \\
\hline USCS Classification & $\mathrm{ML} / \mathrm{CL}$ & $\mathrm{SC}$ & SM \\
\hline $\mathrm{w}(\%)$ & 5.06 & 16.3 & 21.5 \\
\hline$\rho\left(t / m^{3}\right)$ & 1.30 & 1.28 & 1.23 \\
\hline$\rho_{i}\left(t m^{3}\right)$ & 1.23 & 1.10 & 1.01 \\
\hline$e_{0}$ & 1.20 & 1.38 & 1.61 \\
\hline fines content $(<0.063 \mathrm{~mm})(\%)$ & 54 & 38 & 19 \\
\hline $\mathrm{w}_{\mathrm{L}}(\%)$ & 30 & 26 & 39 \\
\hline $\mathrm{I}_{\mathrm{P}}(\%)$ & 9 & 7 & $/$ \\
\hline$w_{\text {ist }}(\%)$ & 17.4 & 15.0 & 27.5 \\
\hline$\rho_{\text {irax }}\left(t / m^{3}\right)$ & 1.65 & 1.77 & 1.34 \\
\hline$c^{\prime}(\mathrm{kPa})$ & 2.3-19 & 1.7 & 0 \\
\hline$\varphi^{\prime}(\mathrm{s})$ & $33-35$ & 37.5 & 38 \\
\hline$\rho_{\text {inax }}\left(t \mathrm{~m}^{3}\right)$ & 1.65 & 1.77 & 1.34 \\
\hline
\end{tabular}

TABLE 2. Properties of three typical groups of soils from the top layer.

the likelihood of liquefaction of level sites (Figure 5 , left). The Cyclic Stress Ratio (CSR) is calculated from Eq.1] 9 .

$$
\begin{gathered}
(C S R)_{M=7,5}=\frac{C S R}{M S F}=\beta\left(\frac{\sigma_{v 0} \cdot a_{\max }}{\sigma_{v 0}^{\prime}}\right) \cdot \frac{r_{d}}{M S F} \\
M S F=6.9 \exp \left(\frac{-M}{4}\right)-0.058 \quad M S F \leq 1.8
\end{gathered}
$$

where $\beta$ is a ratio between real maximum and equivalent seismic stresses $(0.65)$ [15, $a_{\max }$ is the maximum ground surface acceleration on the foundation ground, $r_{d}$ is stress reduction factor that drops from 1 at the surface to about 0.9 at $10 \mathrm{~m}$ depth. $M S F$ is a factor to account for the varying number of cycles associated with different magnitude events and has values shown in Table 1

The Seismic Dilatometer Tests (SDMT) in top layers gave the shear wave velocities $\left(v_{s}\right)$ of $160-300 \mathrm{~m} / \mathrm{s}$, while the seismic refraction test indicates the vs of 90-110 m/s. Seed and Idris [14, Youd et al. [16] and Andrus [17] proposed an empirical relation for assessing the likelihood of liquefaction of level sites, based on relationship between the CSR and $v_{s}$ (Figure 5 , right).

The Cyclic Simple Shear Test (CSST) was used to study the influence of the density on the liquefaction potential (Figures 677). The tests were carried out on soil samples with properties given in Table 2 Specimens were prepared at different initial void ratios, saturated, consolidated at $75 \mathrm{kPa}$ of effective stress and then loaded with horizontal sinusoidal load at desired stress ratio in undrained condition. The beginning of liquefaction was defined when the increase of pore water pressure was equal to $95 \%$ of effective vertical stress before cyclic loading. The reference number of cycles was defined after Kramer [18, for an earthquake of magnitude 7.5.
Results of the laboratory tests are given in Figure 7 and confirm that the top layer soil are prone to liquefaction. The compacted soil samples at $95 \%$ of maximum Proctor density (DPR) will very probably resist the 475 year return period earthquakes and will very probably liquefy at stronger earthquakes.

\subsection{Preliminary Conclusions}

The grain size distribution, the SPT, the seismic refraction as well as CSST indicate the same ranges of liquefaction potential and can be estimated as valid and reliable. The test results can also be confirmed by the historical data from the 1880' Zagreb earthquake. The SDMT test gave the shear wave velocities $\left(v_{s}\right)$ in a range of $160-300 \mathrm{~m} / \mathrm{s}$. Comparing the SDMT test results with other tests as well as with calculation, using the empirical equation 3 and 4 , explained in chapter 4, we may conclude, that the SDMT test values are too high for the top soil layer - probably affected by field site heterogeneity or by the influence of other men activities.

Based on other tests the conclusions are clear: the top layer represents a very unfavourable foundation ground and must be improved or removed from the influential area of the dikes.

\section{Discussion on Improvement TEChNique}

Several options were discussed to improve the liquefaction resistance of the foundation ground, as follows:

- Loose material from the top layer shall be removed and replaced with compacted gravel material. The idea was recognized as the most promising and reliable choice as large quantities of good quality gravel material are available at the location. However, due to the large volumes of top soil to be replaced (length of app. $14 \mathrm{~km}$, depth up to $5 \mathrm{~m}$, width that locally exceeded $50 \mathrm{~m}$ ) the decision was made to investigate other options too. 

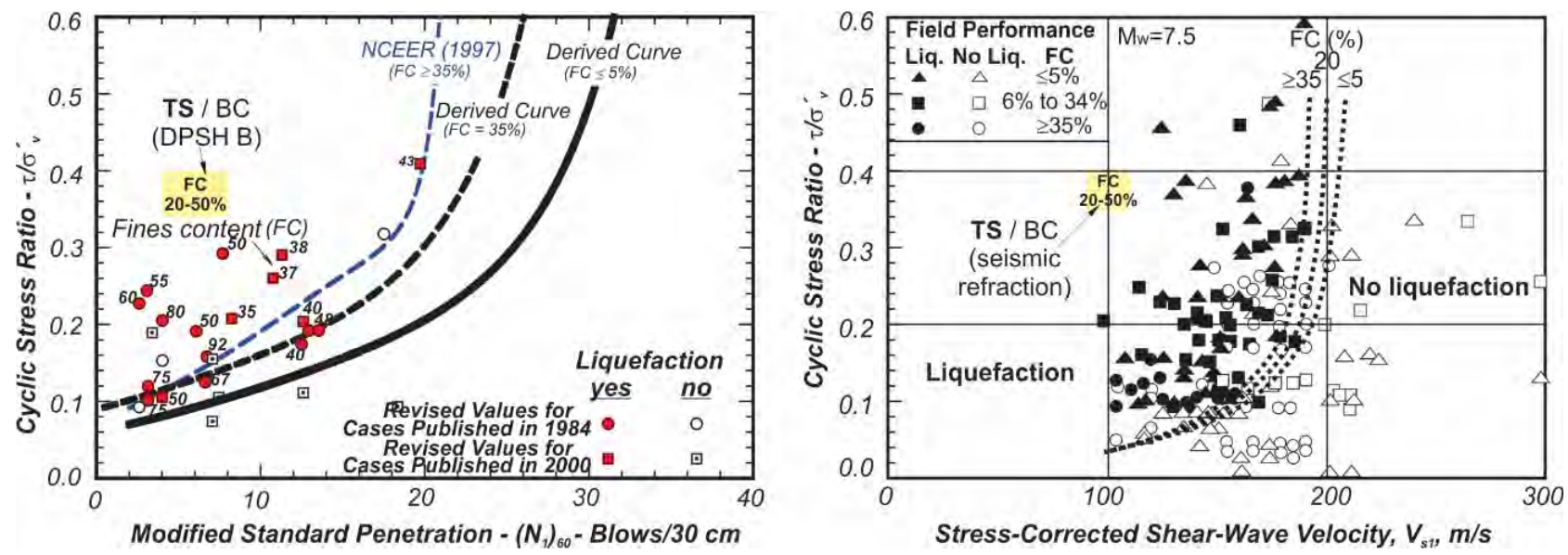

FigURE 5. Relationship between cyclic stress ratios causing liquefaction and $\left(N_{1}\right)_{60}$ (after Seed and Idriss [14]) and the position of the top soil in it (left). Relationship between cyclic stress ratios causing liquefaction and shear wave velocity values (after Seed and Idris [14, Youd et al. [16 and Andrus 17) and the position of the top soil in it (right). BC - before compaction, $\mathrm{FC}$ - fines content, TS - top soil layer.
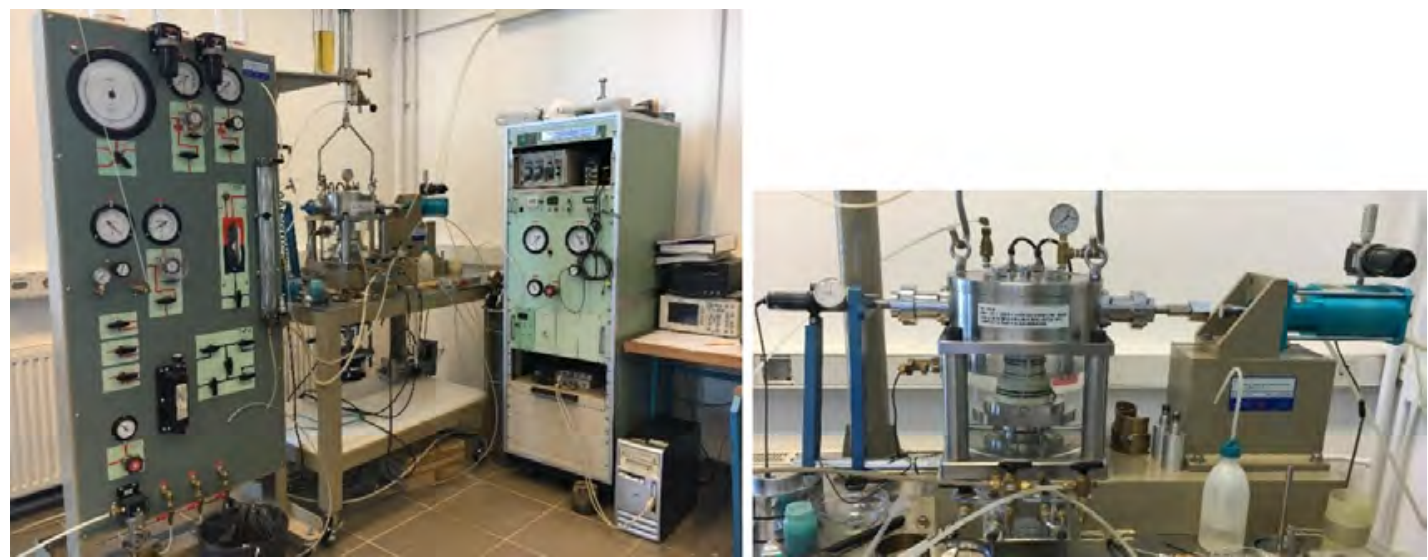

Figure 6. The Seiken cyclic simple shear apparatus, used for the laboratory tests (left) and the cell (right).

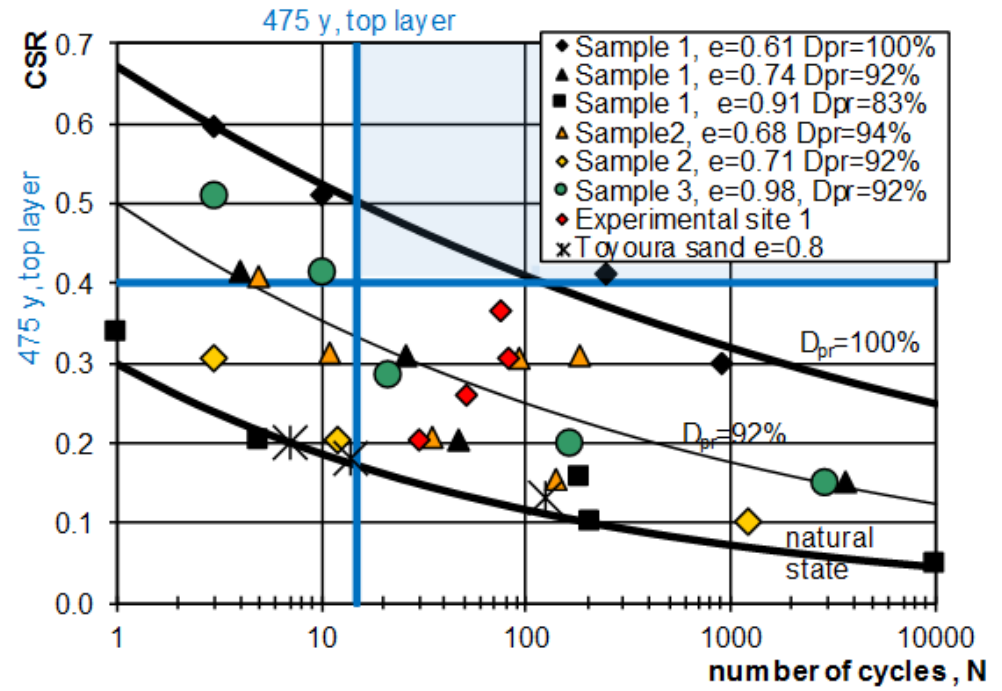

FiguRE 7. The relationship between the number of cycles needed for liquefaction and the cyclic stress ratio (CSR) for top soils at different void ratios. 
- Option 1 (ES 1): Static and vibratory roller compaction. The main attention was paid to the following questions: (a) is the $95 \%$ of max. Proctor density attained on site, (b) what is the effective depth of the roller compaction and (c) what are the potentially harmful effects of coal particles and roots to the soil compaction behaviour? The four test fields were made to study the compaction efficiency of the foundation ground and up to $2.5 \mathrm{~m}$ high test embankment was constructed to study the roller compaction efficiency above the soft subgrade, the vertical and horizontal movements, the internal erosion and to analyse the sensitivity of different test methods, like Cone Penetration Test (CPT), Flat Dilatometer Test (DMT, SDMT), Dynamic Probing Super Heavy (DPSH B), etc. The test field was made in September and October 2009.

- Option 2 (ES 2): Rapid Impact Compaction (RIC). To avoid the shortcomings of the shallow effects of roller compaction, the RIC technique was proposed. Two test sites were made in February 2011. A comprehensive investigation was made on site before and after compaction [19, 20].

- Option 3 (ES 3): Soil mixing on site to achieve liquefaction resistance, low permeability and better willingness to compaction. The idea was to excavate top soil and mix it with Quaternary gravel in such proportion that it would fulfil three criteria: (a) resistance against liquefaction, (b) the designed permeability to eliminate the need for additional sealing of the dike and (c) improved willingness to compaction with reduced influence of seasonal water content changes on stiffness. The trial tests were made in April and May 2014, and the roller with the Roller Integrated Continuous Compaction Control (CCC) was used for compaction. As the trial fields showed promising results, the temporary, app. $1.2 \mathrm{~km}$ long dike was constructed in order to protect the deep excavation for the powerhouse against the floods, as well as to get more data about the homogeneity, permeability and the resistance against liquefaction of the dike. Figure 8 shows the locations of the field trial tests ES 1 to ES 3 and the temporary dike.

\section{Results FROM the EXPERIMENTAL SITES}

\subsection{Experimental Site ES 1: Roller COMPACTION TRIAL FIELD}

\subsubsection{SITE DESCRIPTION}

The soil profile and the soil properties were the same as presented in Figure 2 and Table 2 The thickness of the top layer was $4 \mathrm{~m}$, the roots appeared in dense network to the depth up to $3.5 \mathrm{~m}$. Figure 9 shows the depth of the roots (left) and the size of the first of four test fields prepared to study the roller compaction efficiency of the foundation ground - subgrade (right). Figure

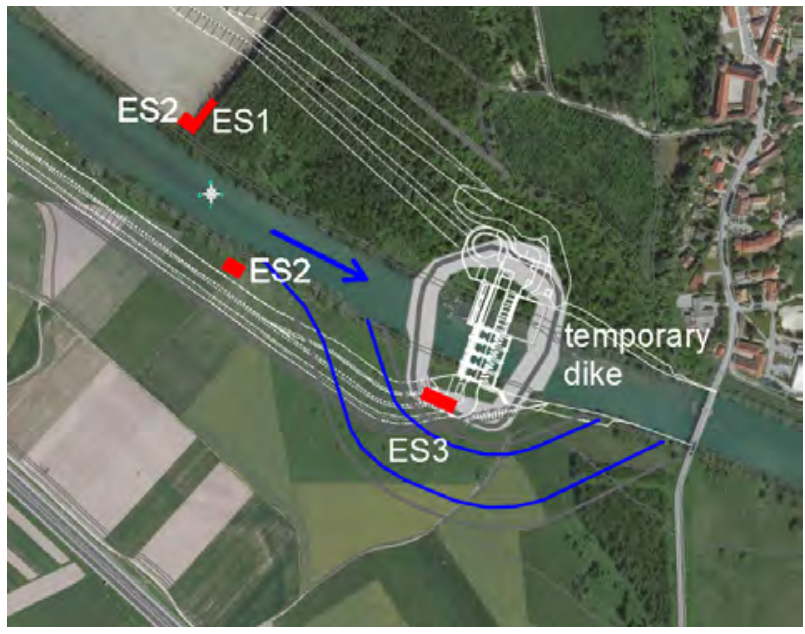

FIGURE 8. Location of the field trial tests: ES 1: roller compaction; ES 2: RIC; ES 3 and temporary dike: soil mixing.

10 shows the test embankment (left), constructed by using the silty sands from the top layer and the amount of coal particles (right) that floated up after the layer wetting. During compaction different modes of roller operation, layer thickness, drying and wetting of compacted layers were studied.

The efficiency of the roller compaction was measured by using the nuclear gauge and by the calibrated cylinders to measure the water content and the density. Stiffness of compacted layers was measured by static and dynamic plate load test. Undisturbed samples were taken to check the liquefaction potential in the CSST. The SPT, CPT and the SDMT tests, planned to be realised at the test sites, were not possible, as the flood destroyed the trial sites soon after construction.

\subsubsection{Results AND Discussion}

At the foundation ground, the roller compaction was found not effective due to the influence of soft sublayers, coal particles and roots. The average achieved $D_{P R}$, expressed as ratio $\rho_{d} / \rho_{d, \max }$, was $88 \%$ and the average stiffness, measured by the dynamic load plate test (ZORN) was $E_{v d}<7 \mathrm{MPa}$.

The efficiency of compaction on embankment layers strongly depended on the layer position above the ground level, as the influence of the soft subgrade decreases with the embankment height. At the level of $2 \mathrm{~m}$ above the subgrade, the average compaction of $D_{P R}=94 \%$ was achieved (Figure 11), while the average stiffness of the embankment layers remained at the same average ranges as measured on the subgrade, $E_{v d}=5-10 \mathrm{MPa}$.

Figure 12 compares the results of dry densities (left) and water content (right), achieved by using the nuclear gauge and the calibrated cylinders. The nuclear gauge gives significantly higher values of water content, which can be explained by the presence of coal particles and the nuclear gauge water content mea- 


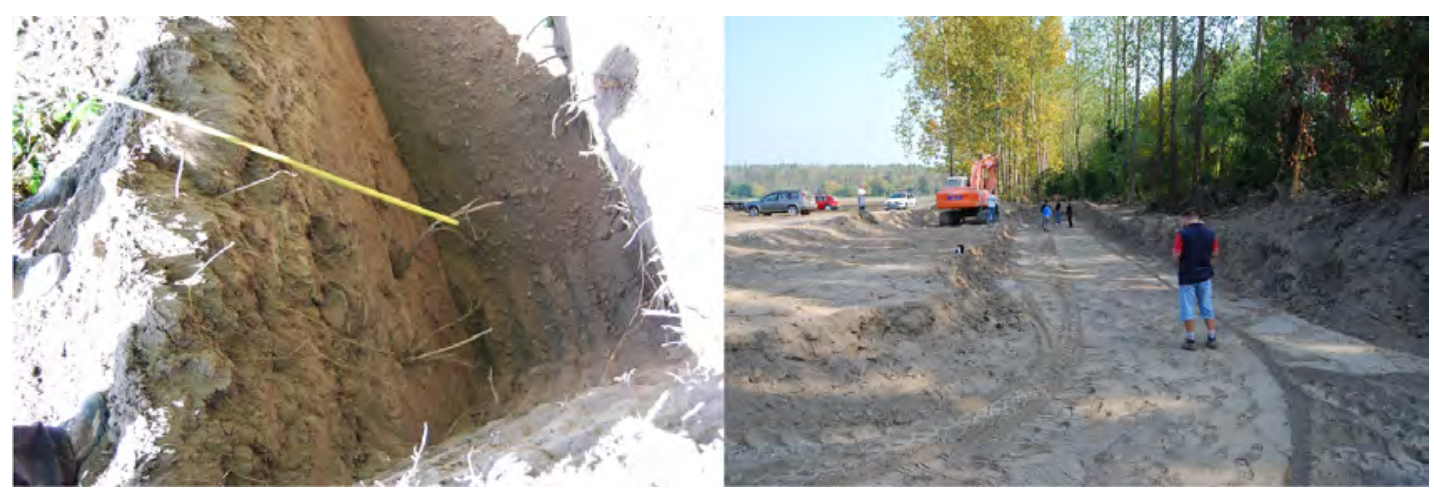

Figure 9. Depth of the roots (left) and the size of the first of four test fields prepared to study the roller compaction efficiency (right).

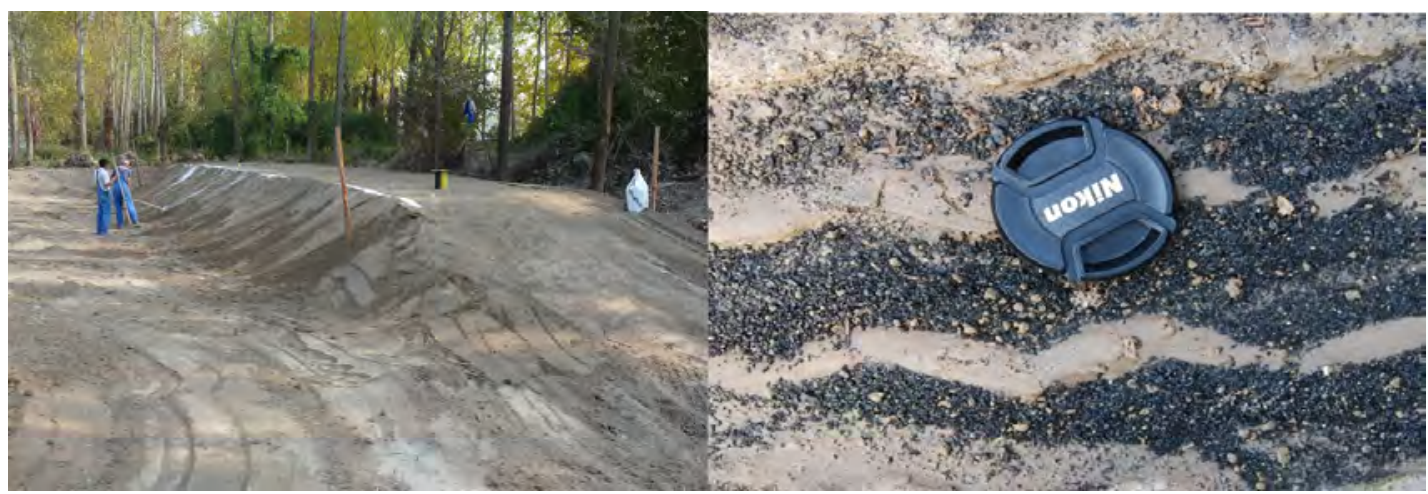

Figure 10. Finished test embankment (left) and the amount of coal particles (right).

suring principles. Figure 7 (red diamonds) shows the CSST results on the undisturbed samples from the test field. The data conform well to the preliminary forecast.

\subsubsection{EXPERIMENTAL SITE ES 1 CONCLUSIONS}

With the use of roller compaction, it is not possible to improve the top soil layer in order to reduce its liquefaction potential. The dynamic and static load plate test results strongly depend on saturation/water content and therefore do not measure parameters, which are decisive for the intended purpose.

\subsection{EXPERIMENTAL SITE ES 2: RAPID IMPACT COMPACTION (RIC) TEST FIELDS}

\subsubsection{BACKGROUND}

The HPP Brežice test sites represented the first attempt to introduce the RIC in Slovenia. The detailed description of the RIC test site is given in Vukadin 20]. To highlight the importance of the test method validity and reliability, we will focus our discussion on the results of the DMT and SDMT tests, not reported in Vukadin 20, as well as on the results of the CPT and DPSH B test, interpreted from a standpoint differing from that of Vukadin [20].

\subsubsection{RIC TEST SITE DESCRIPTION}

The locations of the test sites are shown in Figure 8 , while a view to the RIC during operation and the test site layout is given on Figure 13 . Rough dimensions of each test field were $18 \times 25 \mathrm{~m}$.

Before the RIC was put in operation, the vegetation layer of app. $1 \mathrm{~m}$ had been removed from the test site. The thickness of the top layer was from 3.8 to $4.0 \mathrm{~m}$, with the fines content between 21 and $66 \%$, water content between 16 and $21 \%$ and the dry densities of $1.2-1.6 \mathrm{t} / \mathrm{m}^{3}[20$. The $\mathrm{GW}$ table was in the Quaternary gravel.

At each test field, a comprehensive program of field tests (CPT, DMT, SDMT, DPSH B and Dynamic Cone Penetrometer (DCP) Panda) was performed before and after compaction. The filed measurements were complemented by samplings from trial pits and laboratory tests.

Each test field was divided in 4 sections ( $\mathrm{P} 1$ to $\mathrm{P} 4$, Figure 13 in order to study the influence of different compaction modes on the compaction efficiency. The compaction point raster density increased from section $\mathrm{P} 1$ to section $\mathrm{P} 4$ and the compaction was executed in one, two or three passes. After each compaction pass the ground was levelled by filling the holes created during compaction with the locally available sand. The decision about the end of the compaction at each point was made considering two criteria: (a) the accumulated total settlement per pas of $800 \mathrm{~mm}$, or (b) the minimal depth of settlement per blow less than $10 \mathrm{~mm}$. The average energy per unit cell area was 800 (P1), 1160 (P2), 1000 (P3), and $1230 \mathrm{~kJ} / \mathrm{m}^{2}$ (P4). 


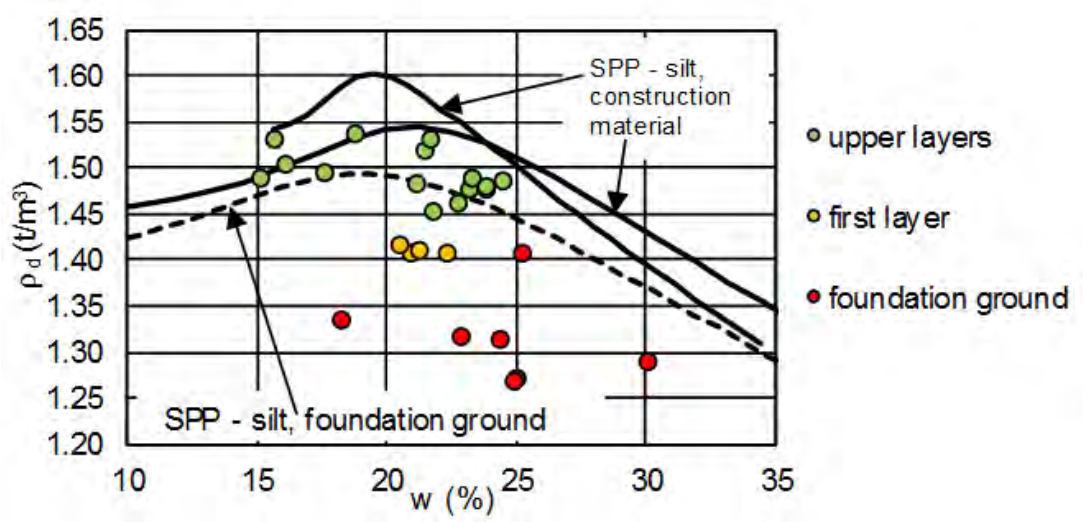

Figure 11. Comparison of standard Proctor test curve (SPP) and dry density achieved during trial embankment compaction.
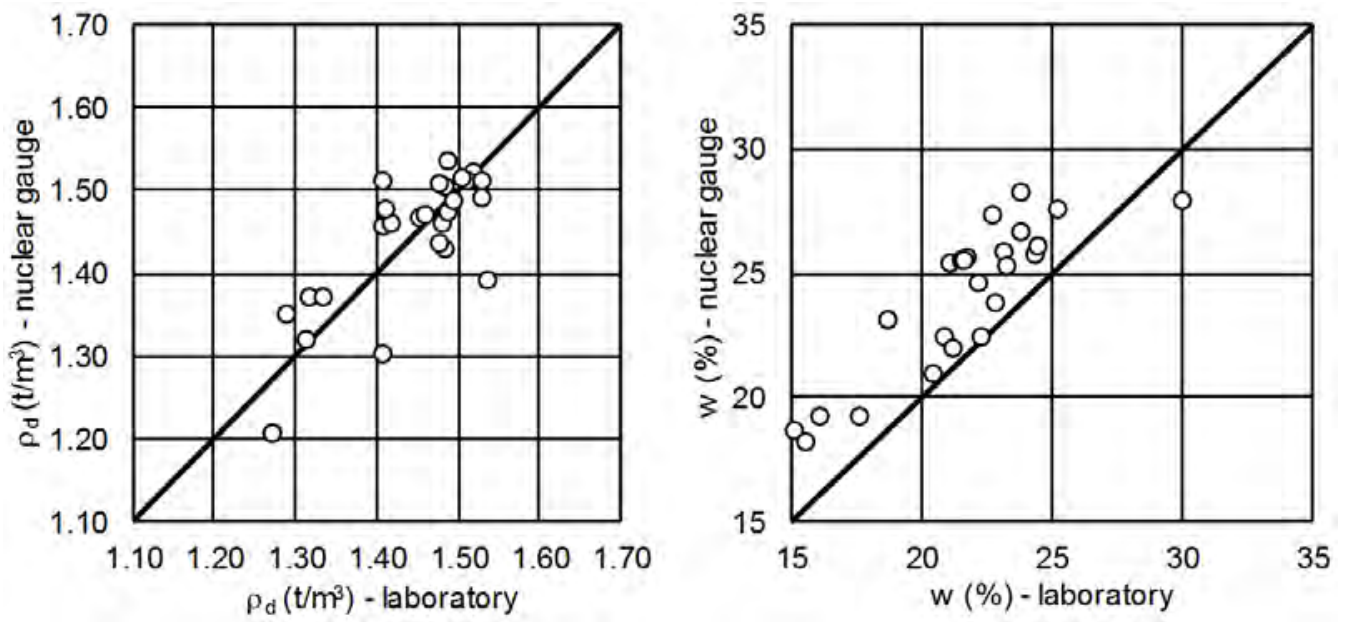

FiguRE 12. Comparison between nuclear gauge and laboratory measurements of water content and dry density.

\subsubsection{RESUltS AND DisCUSSION}

The efficiency of RIC was controlled by using different field test methods. This paper will focus primarily on the interpretation of the CPT, SDMT and DPSH B results.

\section{CPT test}

Figure 14 shows the soil behaviour type $\left(S B T_{n}\right)$, the normalized cone resistance $\left(Q_{t n}\right)$ and the sleeve friction resistance $\left(f_{s}\right)$ evaluated from the CPT test. The $Q_{t n}$ is a non-dimensional parameter taking into account the in-situ vertical effective stress and the soil type and is not depth dependent. The $f_{s}$ depends on friction between soil and metal sleeve and horizontal effective stress. The horizontal stress increases with vertical effective stress $\left(\sigma_{v}^{\prime}\right)$ and could be calculated by multiplying $\sigma_{v}^{\prime}$ with horizontal stress coefficient during the CPT testing. The influence of compaction on the $f_{s}$ is given in two diagrams, as the relationship $f_{s}-$ depth and $f_{s} / \sigma_{v}^{\prime}$ - depth. The $f_{s} / \sigma_{v}^{\prime}$ diagram presents the increase of horizontal stress coefficient during the CPT testing due to compaction.

Due to the impact of levelling of ground surface, the uppermost $1 \mathrm{~m}$ of the test field is excluded from the evaluation of the results.

Figure 14 shows that classification based on $S B T_{n}$ was not changed due to compaction (5: sand mixtures - silty sand to sandy silt and 6: sands - clean sand to silty sand).

The $Q_{t n}$ increases from the initial 40 to 60-160 after the RIC. In natural ground the $f_{s}$ is increasing with the depth. After compaction the $f_{s}$ increases slightly to the depth of $1.5 \mathrm{~m}$. At the depth of $1.5 \mathrm{~m}$ the sharp increase of $f_{s}$ is detected towards the value of $100 \mathrm{kPa}$. The $f_{s} / \sigma_{v}^{\prime}$ is constant with the depth before RIC, thus indicating homogeneous ground conditions. After the RIC the highest increase of $f_{s} / \sigma_{v}^{\prime}$ is observed at the depth of $1.6 \mathrm{~m}$ and then decreases with the depth towards the initial value at the depth of $4 \mathrm{~m}$. The CPT test did not recognize effects of different compaction energies on the increase of $Q_{t n}$ and the $f_{s}$.

Figure 15 compares the $Q_{t n}$ and the $f_{s}$ before and after RIC. After compaction the $Q_{t n}$ is 2 to 4 times higher and the $f_{s}$ is 2 to 6 times higher than before compaction. Below the depth of $3 \mathrm{~m}$ the effect of RIC is decreased. No influence of different compaction energies used for the compaction can be recognized.

(S)DMT test

The results of the DMT test are presented as intermediate parameters: material index $\left(I_{D}\right)$, horizontal 


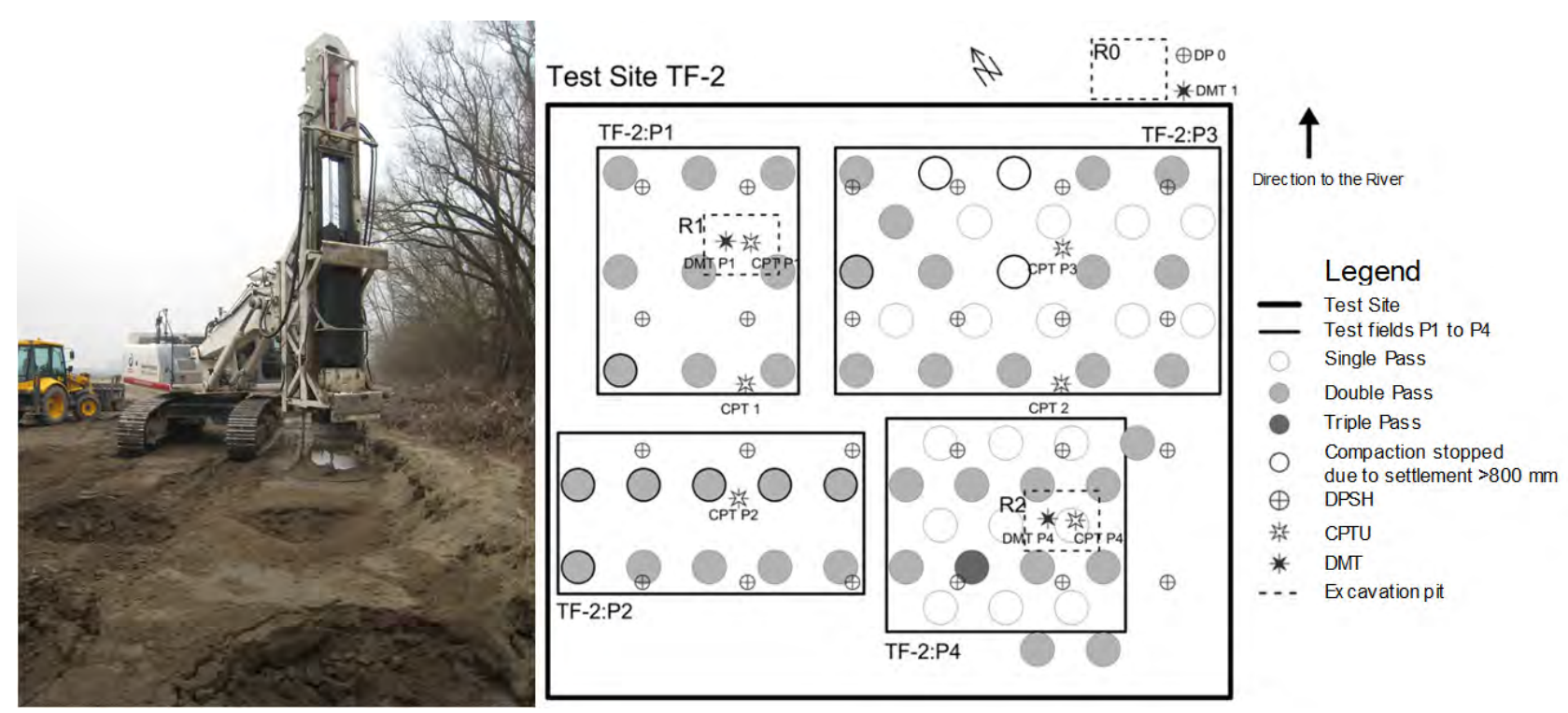

Figure 13. RIC during compaction (left) and the test site ES 2 layout (right - adapted from Vukadin, 20]).
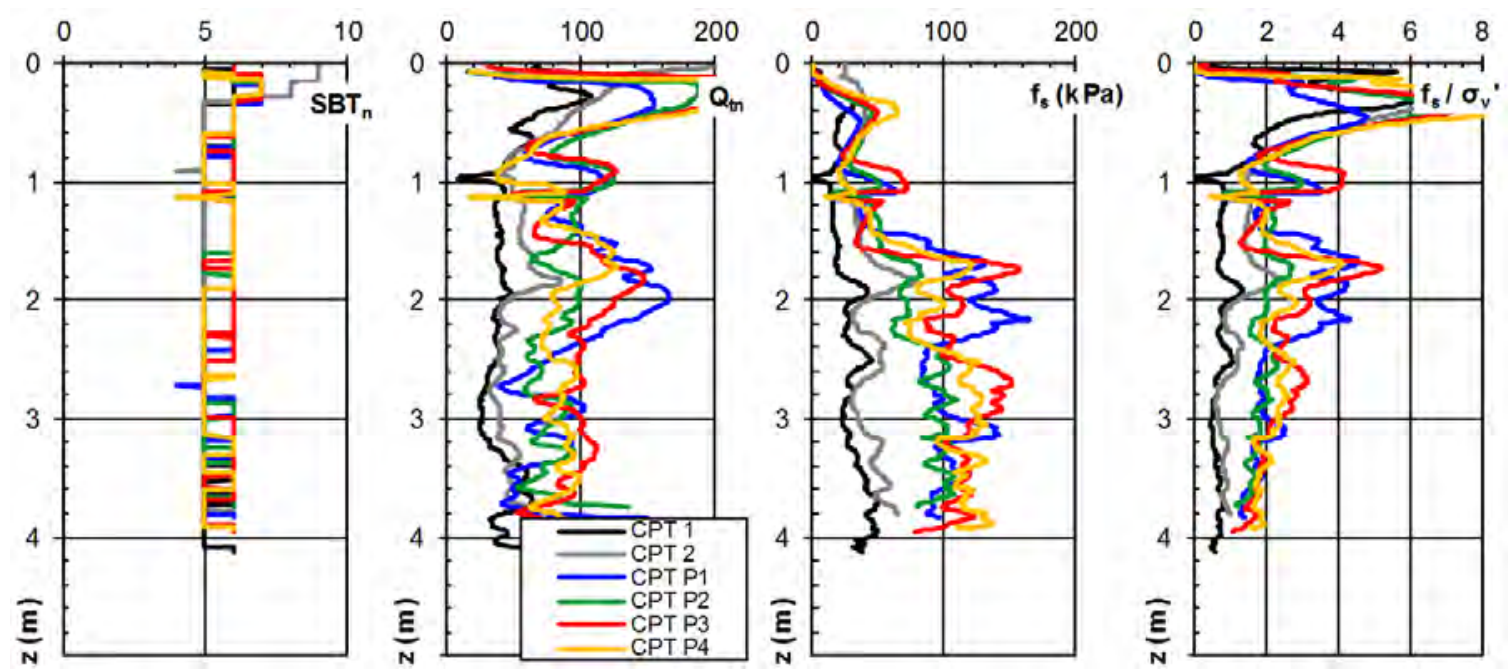

Figure 14. Results of CPT tests. CPT 1 and CPT 2 before RIC, CPT P1 to CPT P4 after RIC performed on sub-fields P1 to P4 (tests performed by IRGO, [19]).
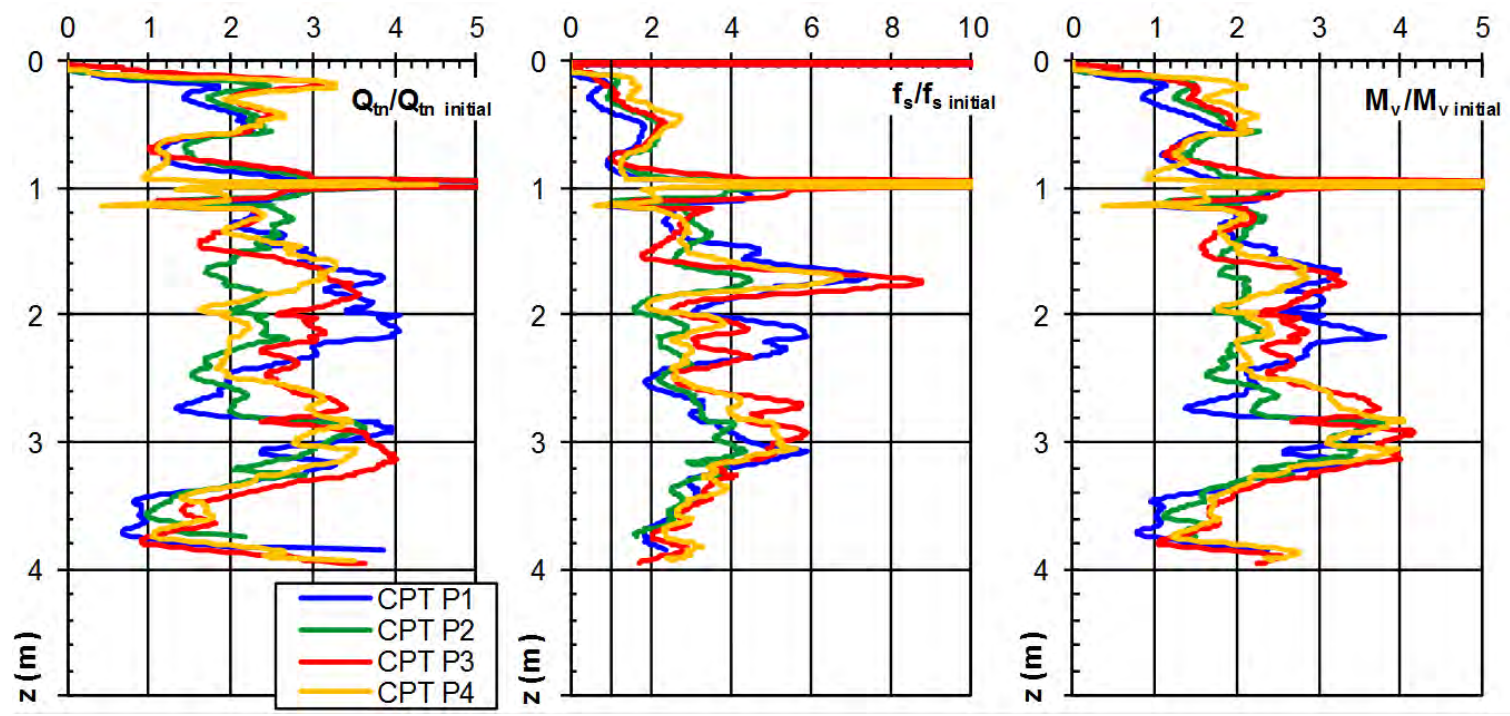

FIGURE 15. Results of CPT after RIC compared to those before RIC (tests performed by IRGO, [19]). 
stress index $\left(K_{D}\right)$, and dilatometer modulus $\left(E_{D}\right)$ (Figure 16). The $I_{D}$ and $K_{D}$ are effective vertical stress independent. The value of $E_{D}$ is presented also in relationship with the vertical effective stress $\left(E_{D} / \sigma_{v}^{\prime}\right)[21$.

Results show that the classification based on $I_{D}$ changed a little due to compaction (mostly sandy silt and silty sand). The general soil behaviour type remains the same.

Below the depth of $1 \mathrm{~m}$, the $K_{D}$ was around 5 before compaction. This value was higher than expected for normally consolidated soils [22]. After compaction the $K_{D}$ first increases and then, below the depth of 2 $\mathrm{m}$, decreases; however, it remains slightly higher than recorded before compaction. The $K_{D}$ is related to $f_{s}$ [23], as the first one gives a ratio between horizontal and vertical effective stress during the driving of DMT, and the second one reflects the friction between soil and metal sleeve induced by horizontal effective stress during the driving of the CPT probe. Therefore, the development trend of the $K_{D}$ with the depth should be of the same range as the developing of $f_{s} / \sigma_{v}^{\prime}$.

The $E_{D}$ increases with the depth before compaction, as expected, and results in higher values after compaction. The $E_{D} / \sigma_{v}^{\prime}$ exhibits nearly constant values with the depth before compaction and clearly increases after compaction.

To estimate the RIC efficiency with the depth, the values of $K_{D}$ and $E_{D}$ before and after compaction are compared (Figure 17). The $K_{D}$ increases by 2 to 3 times and the $E_{D}$ increases by 2 to 4 times. The DMT tests after compaction exhibit almost no increase of $K_{D}$ and $E_{D}$ at the depth of 2 to $2.5 \mathrm{~m}$. At the depth of $3 \mathrm{~m}$ both parameters start to decrease towards the values measured before compaction; however, the decrease is not as clear as in case of CPT. Contrary to the CPT results, the DMT shows clear influence of compaction energy on the increase of the measured values.

The SDMT enables measurements of shear wave velocity $\left(v_{s}\right)$. Shear wave velocity depends on void ratio, effective vertical stress, stress history, cementation and over-consolidation (OCR) ratio [24]. The increase of all parameters with the exception of void ratio increases the $v_{s}$. During compaction the void ratio decreases and the OCR increases. Thus, the increase of $v_{s}$ is expected.

Figure 18 compares the constrained moduli $\left(M_{V} / C P T\right.$ and $\left.M_{D} / D M T\right)$ and the $v_{s}$ before and after RIC. The right graph gives also the lines of $v_{s}$, calculated by using the empirical equation (3) given by Hardin and Drnevich [25].

$$
\begin{gathered}
G_{\max }=1230 \cdot \frac{(2.973-e)^{2}}{(1+e)} \cdot(O C R)^{K} \cdot p^{\prime \frac{1}{2}} \\
G_{\max }=\rho \cdot v_{s}^{2}
\end{gathered}
$$

where $G_{\max }$ is shear modulus at small deformations, $\rho$ is density, $e$ is void ratio, $O C R$ overconsolidation ratio, $K$ is empirical material factor (depends on plasticity index) and $p^{\prime}$ is mean effective stress.

Figure 18 shows that before compaction, the $v_{s}$, calculated after Hardin and Drnevich [25], is lower than measured and after compaction the calculated $v_{s}$ is close to the measured. When comparing the measured values of $v_{s}$ before and after compaction, no improvement and no influence of the compaction energy can be detected.

CPT and DMT show the increase of constrained modulus $\left(M_{V}\right.$ and $\left.M_{D}\right)$ after compaction. The range of measured values after compaction is similar. This is not in accordance with the findings reported by Schmertmann [26], Lee et al. [27, among others, who found the increase of DMT constrained modulus $\left(M_{D}\right)$ higher than that of $\mathrm{CPT}\left(M_{V}\right)$.

Dynamic Probing Super Heavy (DPSH B)

DPSH B raw results are presented in Figure 19 (upper line). Before compaction the number of blows $\left(N_{20 S B}\right)$ increases slightly with the depth. The $N_{20 S B}$ values are lower than minimum required (5) according to EN ISO 22476-2. After compaction the $N_{20 S B}$ values are higher and nearly constant with the depth, but the scatter of the result is high. From the $N_{20 S B}$ the equivalent SPT blow-count $\left(N_{1}\right)_{60}$ was calculated using the empirical equation (5) adapted after MacRobert et al. 28] and using corrections given by EC 7.2 .

$$
\text { Equivalent } N_{S P T}=\frac{N_{20 S B}}{0.02 \cdot N_{20 S B}+0.53}
$$

DPSH B clearly indicates the efficiency of RIC and the influence of compaction energy on the increase of the measured values. From this point of view, the sensitivity of the DPSH B test could be estimated as more indicative for the intended purpose than the sensitivity of CPT, DMT and SDMT methods. Contrary to CPT and SDMT, the DPSH B confirms the compaction efficiency along the whole depth of the top layer, which was not observed by using the CPT and SDMT. The question for the discussion is: which method could be estimated as decisive? Can we estimate the efficiency of the improvement by preferring optimistic test results (DPSH B) and neglecting less optimistic (CPT, SDMT) results?

Experimental site ES 2, conclusions

The analysis of the test results confirm that the $\mathrm{RIC}$ technique is an effective tool for improving the geotechnical properties of silty and sandy soils, as it was already reported by Adam and Paulmichl [29].

However, the decision about the use of the RIC technique to reduce the liquefaction potential must rely on the test results which are consistent and confirm without any doubts the efficiency of the improvement. As it was shown in the graphs, the scattering of the collected data raises serious questions about the validity, sensitivity and reliability of the test methods used to confirm the RIC efficiency as well as questions about the homogeneity of the improvement. Analysis of the results shows: 

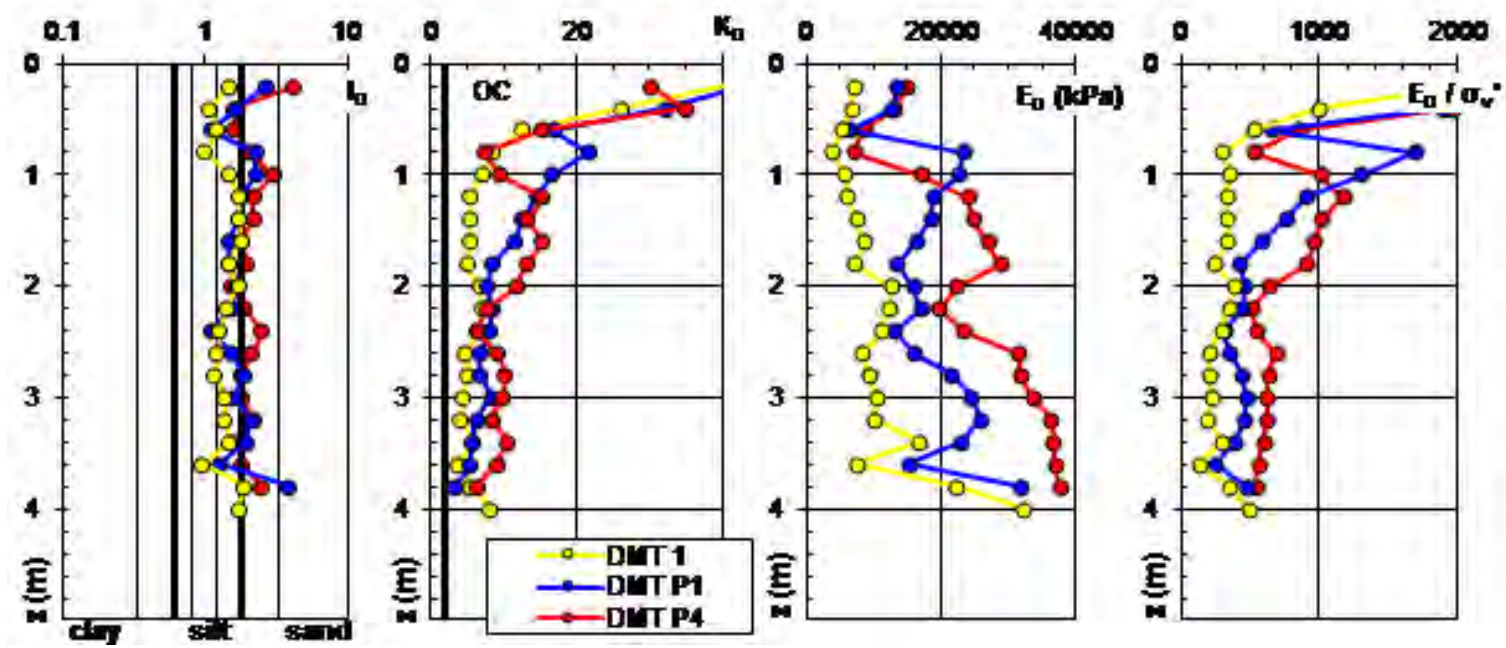

Figure 16. Intermediate DMT results. DMT 1 before RIC, DMT P1 and DMT P4 after RIC performed on sub-fields $\mathrm{P} 1$ and $\mathrm{P} 4$.
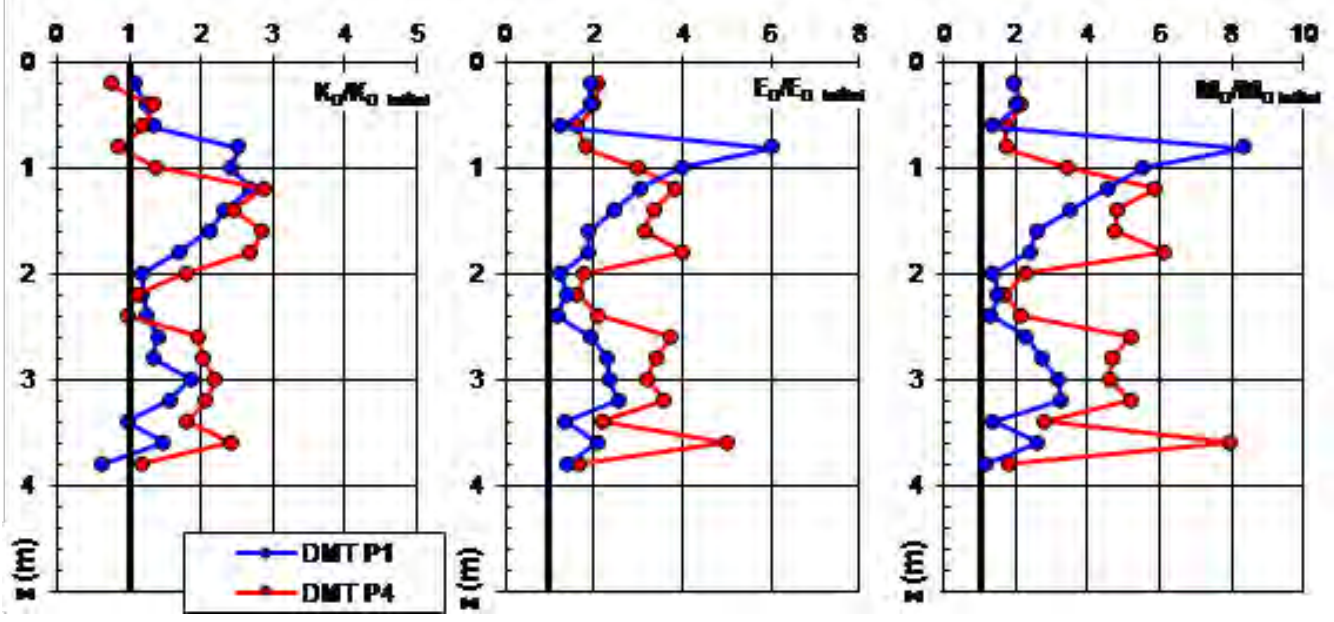

FIGURE 17. Results of SDMT after RIC compared to those before RIC.

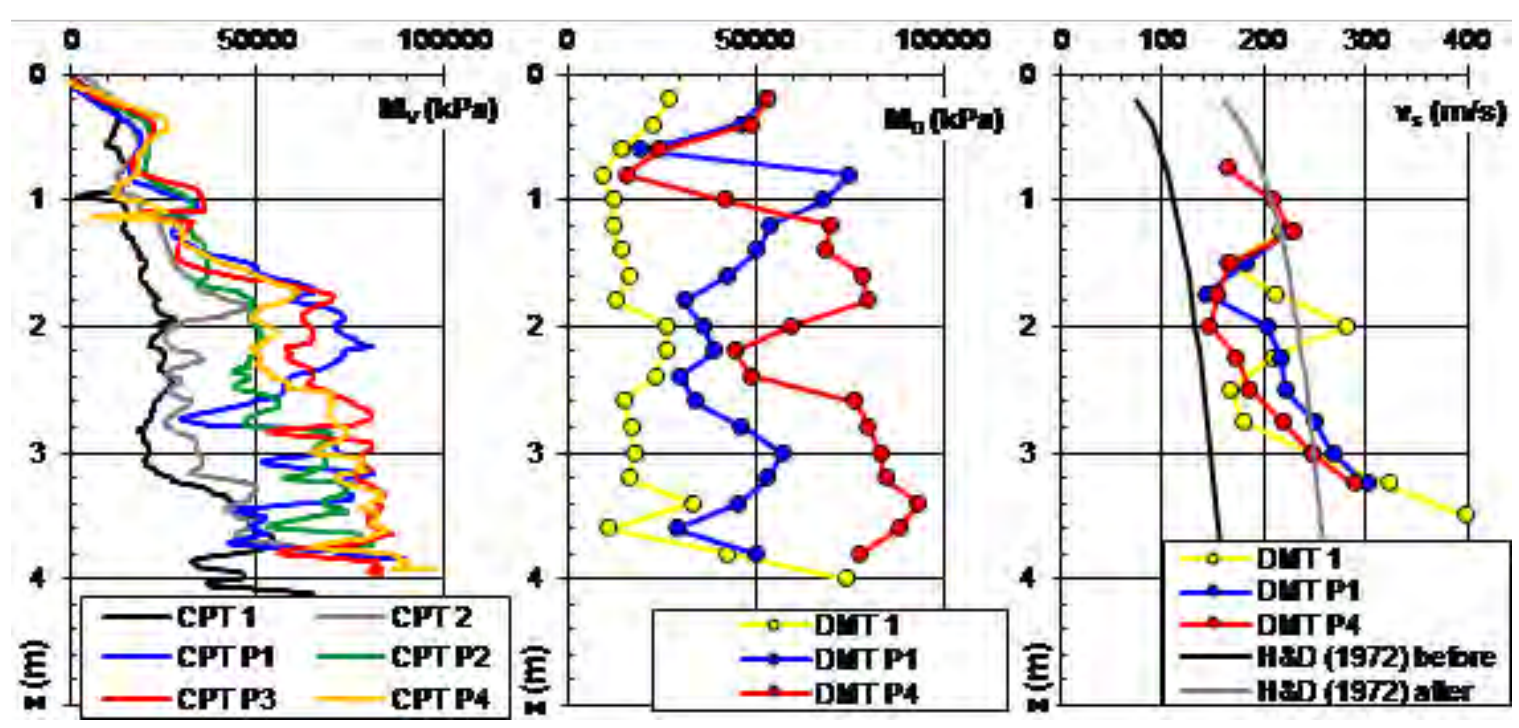

Figure 18. Constrained modulus (MV-CPT and MD-DMT)and measured/calculated $v_{s}(\mathrm{SDMT})$ 


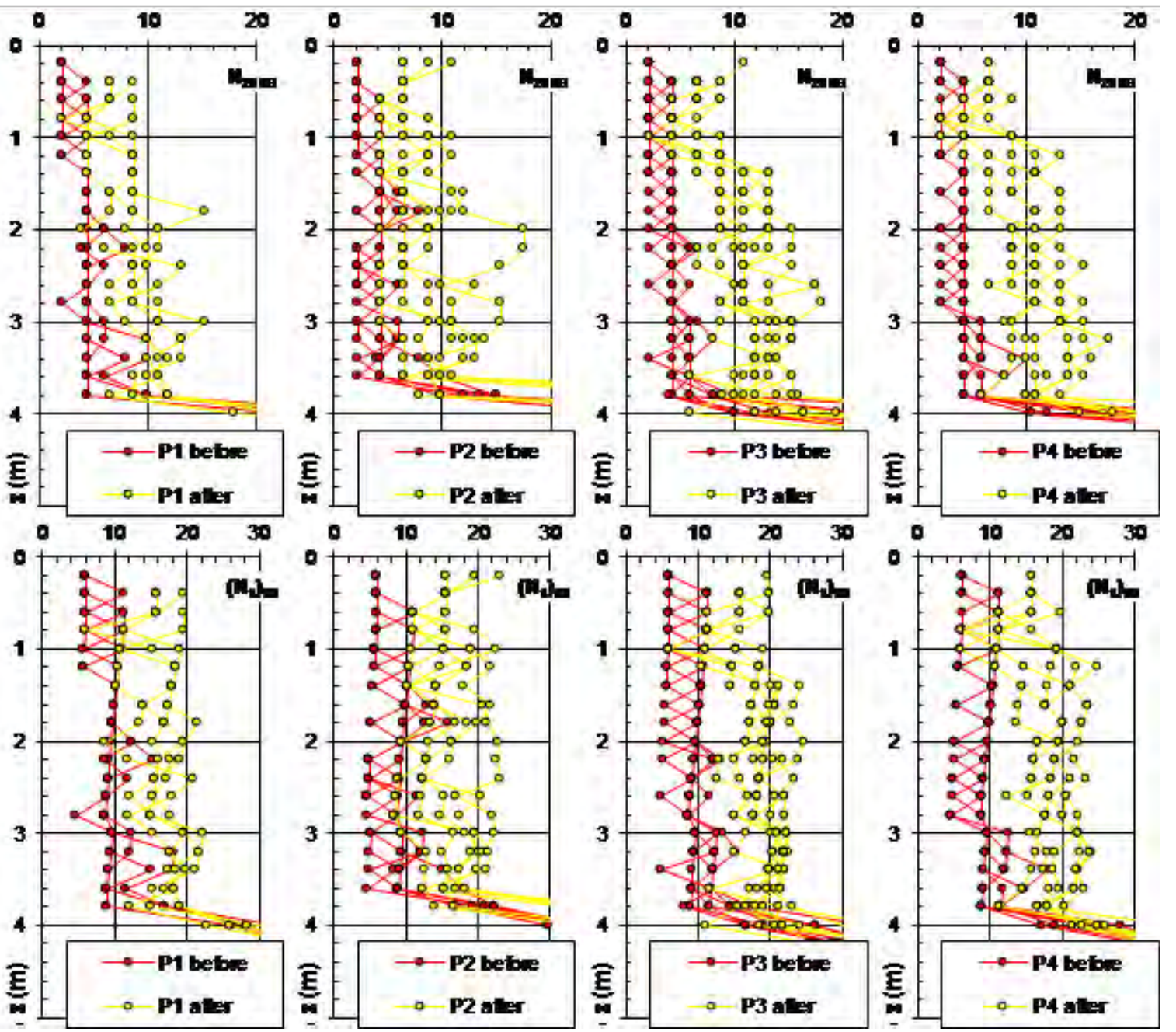

Figure 19. Comparison of $N_{20 S B}$ and calculated $\left(N_{1}\right)_{60}$ values before and after compaction (tests performed by IRGO, 19]).

- the CPT and the DMT do not confirm the compaction efficiency along the whole depth of the top layer, while the DPSH B does

- the CPT does not recognize the effect of compaction energy on the interpreted values, while the DMT and the DPSH B do

- the $\operatorname{SDMT}\left(v_{s}\right)$ does not recognize any improvement after compaction

- the CPT and the DMT clearly recognize the less effective compaction at the depth of $2 \mathrm{~m}$, while the DPSH B does not.

Although the DPSH B tests clearly show the efficiency of RIC, the achieved improvement does not satisfy the criteria needed to reduce the liquefaction potential (Figure 19).

Due to lack of previous experiences with the RIC technique in Slovenia and inconsistency of the test results, the RIC technique was not recognized as a promising method for reducing the liquefaction potential. However, the authors of the paper believe that by preparing more test fields and by using slightly modified execution of RIC and field testing, the results would be different and very probably more promising, too.

\subsection{ExPERIMENTAL Site ES 3: SoIL Mixing}

4.3.1. BACKGROUND

The idea of soil mixing arose by joining three demands: (a) to reduce the liquefaction potential of silty-sandy soils, (b) to assure low enough permeability to avoid any additional sealing of the dikes, and (c) to improve the mixture willingness to compaction.

\subsubsection{SOIL MIXING TEST SITE DESCRIPTION}

Figure 8 shows the location of the test site and Figure 20 gives a view to one of the test sites during test compaction and calibration of roller with CCC.

As the results from the test fields were promising, an app. $1.2 \mathrm{~km}$ long temporary dike was constructed to protect the up to $70 \mathrm{~m}$ deep excavation and to gain additional data necessary to support the decision for the construction of $14 \mathrm{~km}$ long dikes (Figure 21).

\subsubsection{SOIL MIXTURE DEMANDS}

Before the soil mixing tests started, the designer prepared the requirement for the soil mixture, as follows: 
- hydraulic conductivity lower than $1 \times 10^{-6} \mathrm{~m} / \mathrm{s}$

- shear strength must assure stable slopes at 1:1.75 $\left(\beta=30^{\circ}\right)$

- homogeneity and good willingness to compaction

- resistance to liquefaction, as already explained in previous chapters.

\subsubsection{TEST PROGRAM}

The test program was divided in five steps, i.e.:

- mixture design, using the Kozeny-Carman equation

- laboratory mixture preparation and testing

- test fields on site to define the mixing and compaction procedures and to correct the laboratory mixture design, if necessary

- construction of temporary dike with the QA-QC control tests during construction, using the CCC and conventional field test methods: the nuclear gauge, the dynamic and static load plate test and the double ring infiltrometer test

- field testing on the temporary dike by using the SDMT, DPSH B and geohydraulic tests in boreholes.

\subsubsection{The LABORATORY MiXTURE DESIGN}

The mixture was proposed by using the Kozeny-Carman semi-empirical equation [30] 31] 32. The equation relates the hydraulic conductivity to specific surface area, porosity and tortuosity. The main obstacle to wider use of the Kozeny-Carman equation is the specific surface area (SSA) of soil particles [33. Carrier [34, among others, proposed the estimation of SSA based on grain size distribution. The derived hydraulic conductivity based on the Kozeny-Carman equation and estimation of the SSA area based on grain size distribution is:

$$
k=1.99 \times 10^{4}\left(\frac{100 \%}{\sum \frac{f_{i}}{D_{i-1}^{0.404} \cdot D_{i}^{0.595}}}\right) \cdot\left(\frac{1}{S_{F}}\right)^{2} \cdot\left(\frac{e^{3}}{1+e}\right)
$$

where $k$ is hydraulic conductivity at $20^{\circ} \mathrm{C}(\mathrm{cm} / \mathrm{s})$, $S_{F}$ shape factor (6 for rounded grains), $D_{i}$ particle size at sieve size i $(\mathrm{cm}), f_{i}$ fraction between sieve i and $\mathrm{i}-1, e$ void ratio (\%).

The problem of the above equation is the determination of the finest fraction. Based on Chapuis in Legare [35], 1/3 of the smallest measured grain size could be used for the estimation of an equivalent grain size of this fraction.

$$
\frac{f_{i}}{D_{i-1}^{0.404} \cdot D_{i}^{0.595}}=\frac{f_{i}}{\frac{1}{3} D_{i-1}}
$$

There are some limitations to the use of the Kozeny-Carman equation:

- not valid for clays
- valid for laminar flow of water (Darcy law) and therefore not valid for clean, coarse gravel with pore size greater than $3 \mathrm{~mm}$ and large hydraulic gradients

- the grains should be rounded or cubic (blocky)

- soils with a long tail of small fractions (soils which are subject to internal erosion and segregation) can make problems. Particles from the tail of small fractions are not in soil matrix but rather on larger grains. In this case the grain size distribution could be corrected by using $20 \%$ of the increase of passing by 10 times of the increase of the grain size [33].

- anisotropy of hydraulic conductivity. It is assumed that the calculated value relates to the vertical hydraulic conductivity.

The grading ranges of the available soils are given in Figure 3 Based on the Kozeny-Carman equation the mixture of sandy and gravely soil was proposed in mass ratio of 20:80 to 25:75 (Figure 22).

\subsubsection{LABORATORY TESTING}

The hydraulic conductivity of sands was measured in the triaxial cell and in variable head permeameters, while gravel and mixtures were tested in a large constant head permeameter. The diameter $(D)$ of the large constant head permeameter was $304 \mathrm{~mm}$ and its height $(h)$ was approximately $600 \mathrm{~mm}$ (Figure 23). There were 9 piezometers on 3 levels to measure the local hydraulic head (total potential). The disadvantage of large constant head permeameter is poor compaction due to thin plastic walls. The smaller constant head permeameter $(\mathrm{D}=150 \mathrm{~mm} \mathrm{~h}=125 \mathrm{~mm})$ enabled proper compaction of soils with maximum grain size of $31.5 \mathrm{~mm}$.

During the gravel tests in large permeameter a non-linear decline of hydraulic head in piezometers was observed. Three hydraulic conductivities were calculated (average, maximum and minimum). This problem indicates possible segregation and anisotropy of compacted gravels.

The results of the tests are presented in Figure 24 The calculated hydraulic conductivity using the Kozeny-Carman equation are in agreement with the laboratory test results. The measured value on different mixtures was up to 10 times different than calculated. The reason for this is very probably in material segregation and imperfect saturation. In general, the laboratory tests confirmed predictions of the Kozeny-Carman equation and the suitability of proposed mixture.

\subsubsection{TEST FIELDS}

The dimension of the test field was app. $50 \mathrm{~m} \times 10 \mathrm{~m}$. Each test field was made of two $55 \mathrm{~cm}$ thick layers of mixture.

At the beginning, due to the rainy weather, it was difficult to assure the homogeneity due to the high 

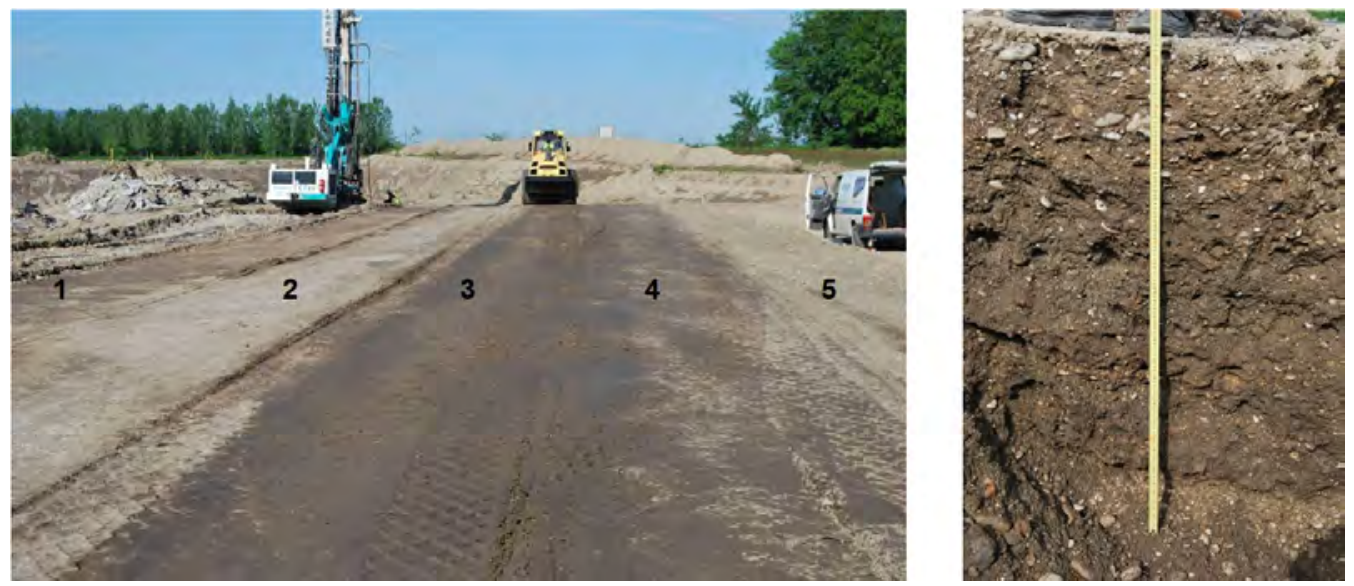

FIGURE 20. Vibratory roller during compaction on one of the test fields (left) and a view to the control pit in one of the test layers (right).

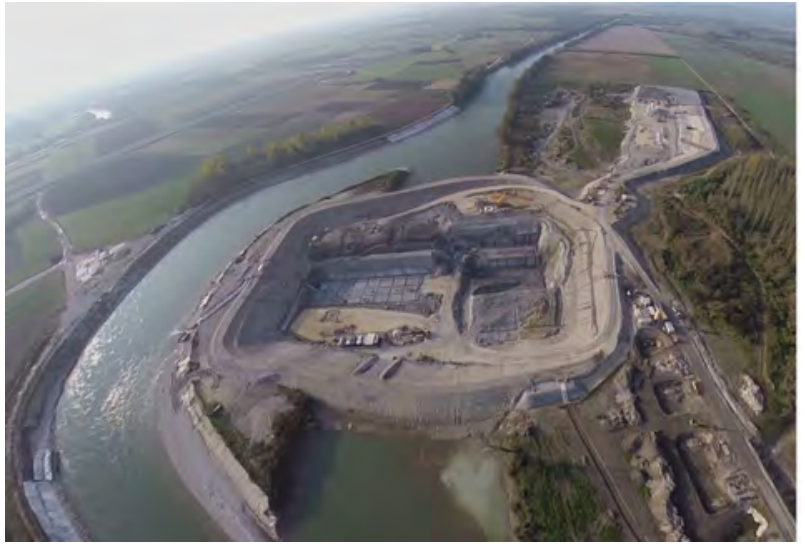

Figure 21. A view to the temporary dike, constructed from soil mixture and used as part of the large scale test embankment.

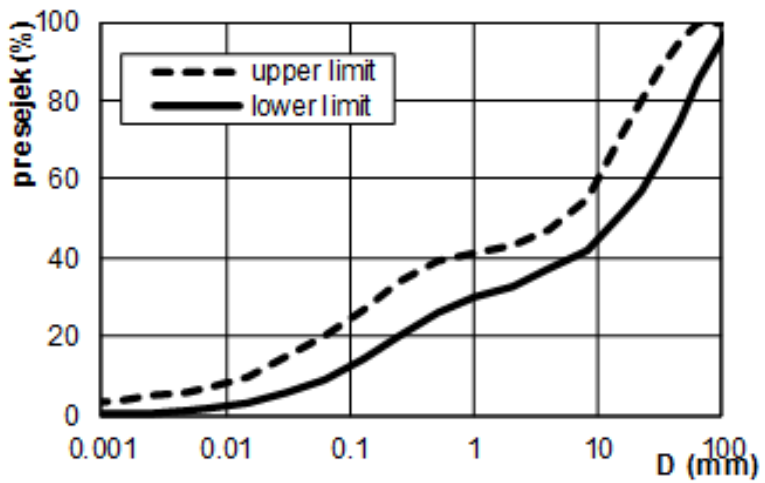

Figure 22. Calculated ranges of soil mixture to achieve the required hydraulic conductivity $(k<$ $10^{-6} \mathrm{~m} / \mathrm{s}$ ) and stiffness. water content of the silty sandy soils. The achieved dry density and stiffness of the mixture were in direct relationship with the water content and the fines content, detected at each controlling point (Figure 25. On mixtures with higher content of fines the achieved layer stiffness after compaction was lower. The difference in stiffness on different test tracks was clearly observed by CCC (Figure 26). Later on, the weather improved and the mixing processes and the compaction ran according to expectations. The decision was accepted to construct a temporary dike by using the soil mixture.

4.3.8. TEMPORARY DIKE CONSTRUCTION CONTROL During the construction of the temporary dike, a comprehensive program of control test was realised, including the 61 sieve analyses and water content tests, 13 double ring infiltrometer tests, 325 spot tests - nuclear gauge. The CCC was used to control the stiffness and homogeneity. 53 gradation curves were inside the required area and 8 samples contained app. 1\% lower content of fines than required. Results of all hydraulic conductivity tests were inside the design requirements (Figure 27). The average achieved density was $98 \%$ of the modified Proctor (MPT) maximum dry density.

\subsubsection{TEMPORARY DIKE POST CONSTRUCTION CONTROL}

Two years after the construction control tests were made from the dike crown. In three bore holes field water permeability (variable head) tests were performed at different depths. Two tests (at depths of 2-4 $\mathrm{m}$ and 4-6 $\mathrm{m}$ ) were performed in the dike and one test (at a depth of 6-8 $\mathrm{m}$ ) in the foundation ground (Figure 27). Four tests in the dike met the design requirements $\left(1 \times 10^{-6} \mathrm{~m} / \mathrm{s}\right)$ and two tests indicated $\mathrm{k}$ higher than required.

Results from four DPSH B probing are presented in Figure 28. As the crown has been used as a temporary unsealed road for the needs of construction site for 2 years, higher $N_{20 S B}$ values were observed at the depths up to $2 \mathrm{~m}$ below the crown. At greater depths 

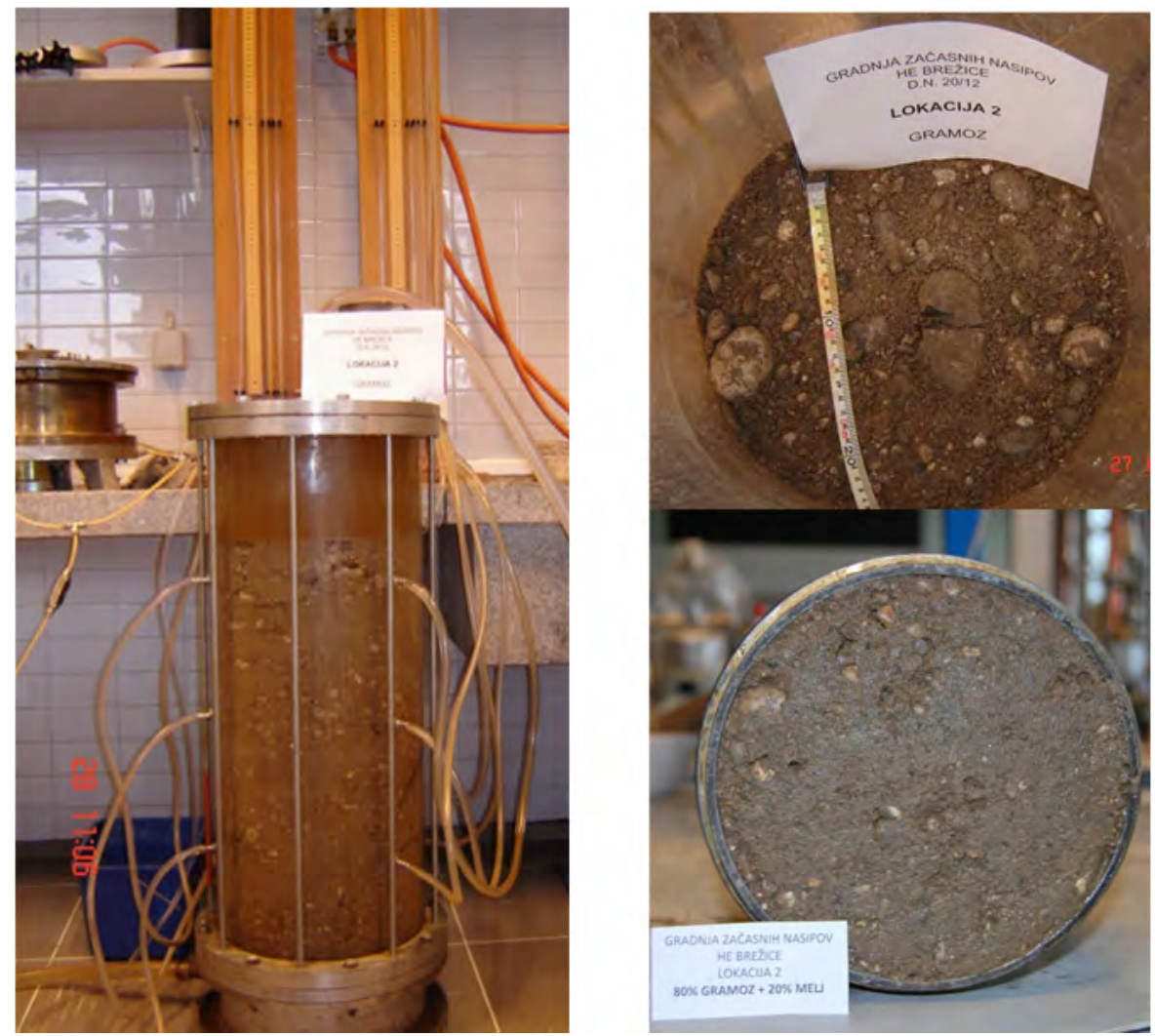

Figure 23. A view to the permeameter cell (left) and a view to the surface of gravel and mixture (right).

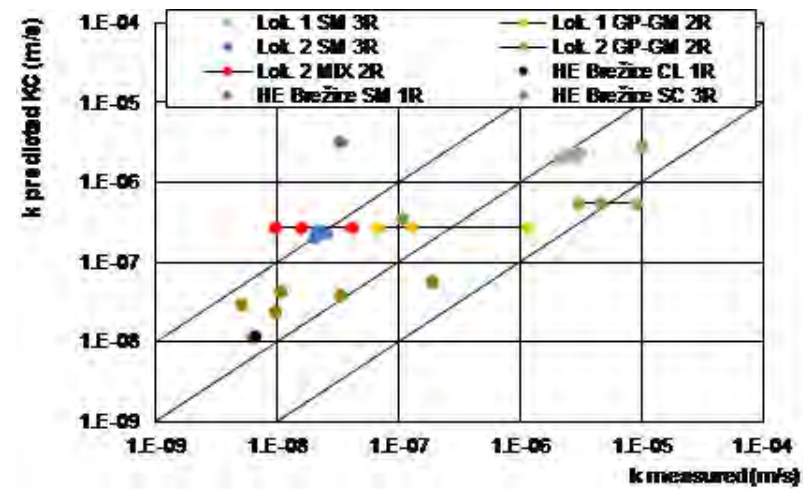

Figure 24. Comparison of calculated (KC) and measured hydraulic conductivity $(\mathrm{k})$.

the $N_{20 S B}$ values were higher than recorded at the RIC test sites.

Three SDMT probings were performed. Before the test started, the boreholes were filled with dry uniform sand. Therefore, a greater variation in result can be expected due to the effects of backfill. The third probe (SDMT3b) was repeated to check the repeatability of the results due to the difficulties during the test in probe SDMT3. The vs results in all probes at the dike were around 200 to $450 \mathrm{~m} / \mathrm{s}$ and were significantly higher than those measured in the top layer before compaction and after the RIC compaction. The measured shear wave velocities are close to the values calculated by using Hardin and Drnevich equation 25] (Figure 28).

\subsubsection{EXPERIMENTAL SITE ES 3 CONCLUSIONS}

The Kozeny-Carman equation was found to be an effective tool for the design of the mixture with the given hydraulic conductivity - considering the equation limitations. The laboratory test and the field double ring infiltrometer test results were in good agreement with the calculation. However, two of six tests in the borehole using open systems gave by a decade higher value of $k$.

The CCC test results show that the compaction behaviour and layer stiffness of sandy gravel mixtures containing app. $10-20 \%$ of fines are mainly controlled by the water content of fines. This means that even though the mixture is classified as silty gravel, its compaction behaviour is typical for less permeable soil mixtures.

The achieved dry density after compaction, the $\operatorname{SDMT}\left(v_{s}\right)$ and the DPSH B tests show that the mixture has properties of gravel. Figure 29 shows that for a given CSR the mixing of locally available soil is a promising method to reduce the liquefaction potential.

However, the decision was made not to use the soil mixing for the construction of the dikes. All the soils from the top layer were removed and replaced by clean gravel. Gravel was also used as fill material for all dikes and the sealing of the dikes was achieved by the geosynthetic bentonite barriers. 

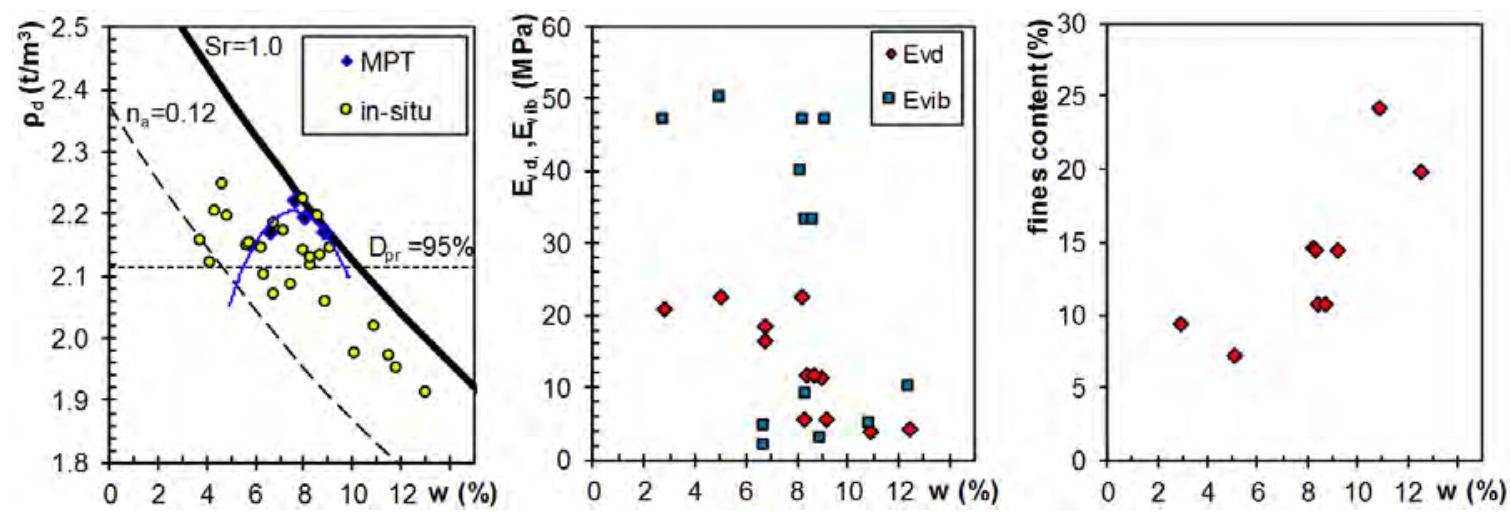

FigURE 25. Results from the first test section. High water content in silty part of the mixture control the achieved stiffness and density. Evd - dynamic deformation modulus measured by dynamic load plate test; Evib - dynamic elasticity modulus of soil beneath drum (Terrameter CCC system).

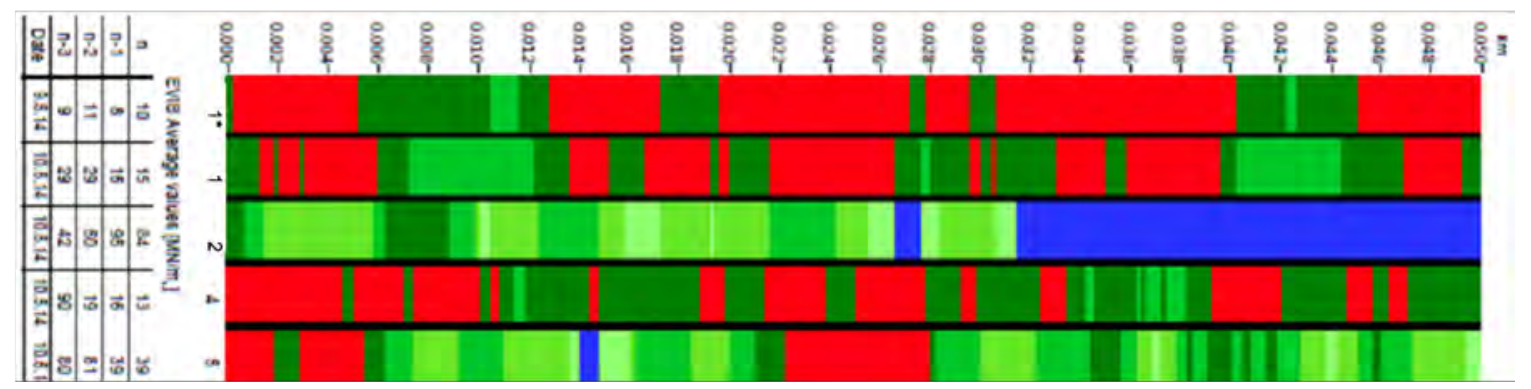

Figure 26. CCC record from one of the first test sections showing heterogeneity of the compaction.

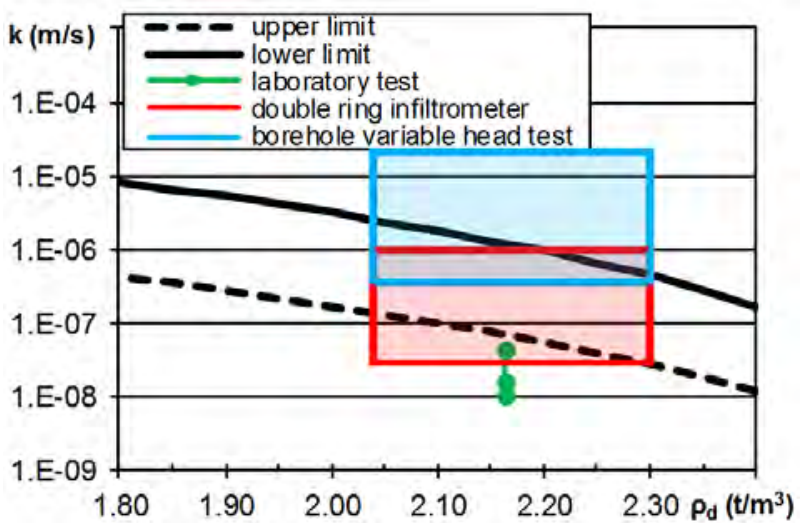

FiguRE 27. Comparison of hydraulic conductivity predicted after Kozeny-Carman equation (upper limit, lower limit) and measured values in laboratory and on site.

\section{Conclusion}

Mechanical stabilisation for ground improvement has become a widely accepted system to support foundations for a wide variety of structures as well as for the construction of embankments and embankment dams. The use of mechanically stabilized locally available soils is also one of the top priorities of the philosophy generally understood as "sustainable development" 36.
The paper focuses on the interpretation of the results of the tests used for the control of the efficiency of some of the stabilisation techniques. The analysis of the tests shows inconclusive results. In foundation ground, where the requirements are different than those given for regular earthworks and the safety demands are higher, the use of different test methods is necessary. Due to the lack of experiences, the use of different methods may lead to inconsistent results and often raises more questions than gives answers. Understanding the local conditions and mechanisms that may influence the test results in different soil types/stabilisation techniques is important for engineering judgement and leads to the ability to make tough decision. However, past experiences are also important and sometimes a lot of time and energy are needed before a new method/ technique becomes widely accepted.

\section{ACKNOWLEDGEMENT}

This work was funded by the HESS and realised in close cooperation with IRGO Ljubljana. Authors would like to express special thanks to Mr. B.Sc. Andrej Unetič (HSE Invest) for his help at realising the investigation program and to many engineers and technicians for their essential field work and data collection. The advice of Prof. Dietmar Adam from TU Vienna is highly appreciated. 

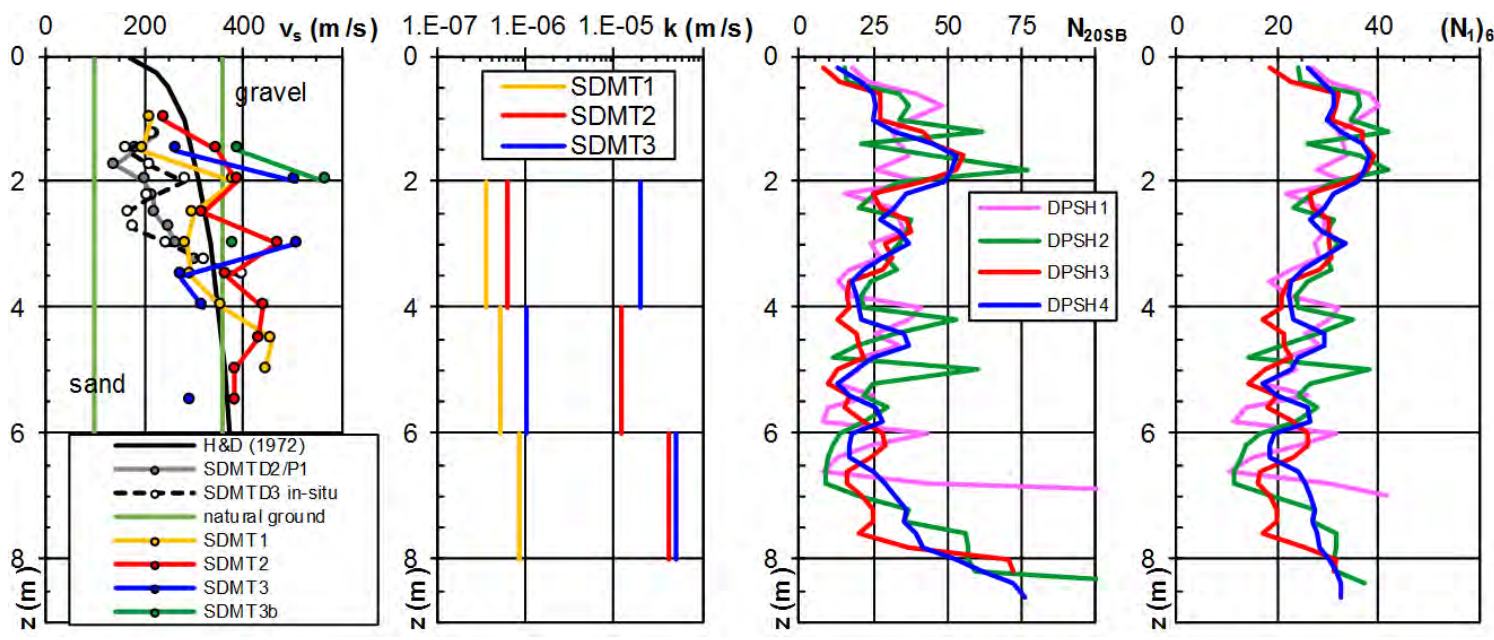

Figure 28. Temporary dike. Shear wave velocity, hydraulic conductivity, and results of DPSH B (from left to right).
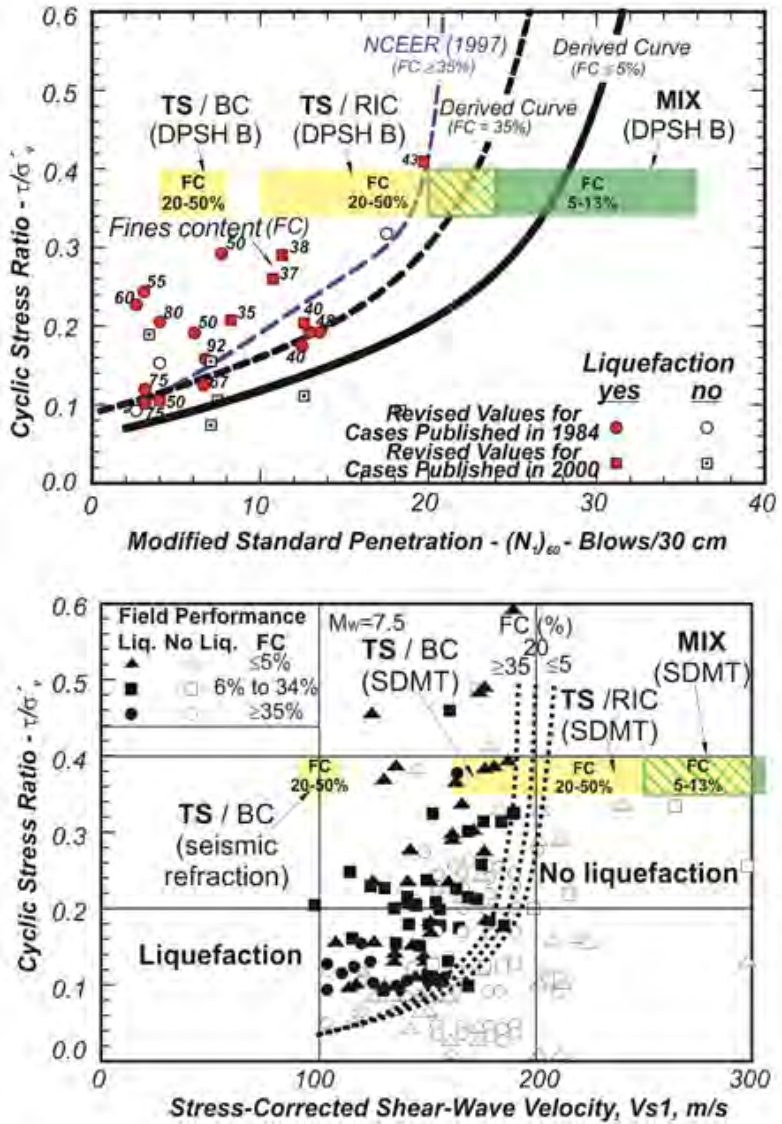

Figure 29. Diagrams for evaluation of liquefaction potential based on $(N 1)_{60}$ (upper) and $v_{s 1}$ (lower). BC - before compaction, FC - fines content, MIX soil mixture, RIC - Rapid Impact Compaction, TS top soil layer.

\section{REFERENCES}

[1] W. F. V. Impe. Soil improvement techniques and their evolution. AA Balkema, Rotterdam, Netherlands., 1989.

[2] H. Brandl. Geotechnics for Roads, Rail Tracks and Earth Structures, chap. The importance of optimum compaction of soil and other granular material, pp. 47-68. CRC Press, 2001.

[3] I. Vaníček, M. Vaníček. Earth Structures In Transport, Water and Environmental Engineering. Springer Netherlands, 2008.

[4] V. R. Raju, J. Daramalinggam. Ground improvement: principles and applications in Asia 165(2).

[5] T. Verbič. Quaternary Stratigraphy and Neotectonics of the Eastern Krško Basin - Part 2: Neotectonics. Razprave IV. Razreda SAZU, XLVI-1, 2005.

[6] V. Ribarič. Seizmičnost Slovenije - Katalog potresov. Seizmološki zavod SR Slovenije, Ljubljana, 1982.

[7] Ž. Veinović, D. Domitrovič, T. Lovrić. Historical occurrence of liquefaction in Zagreb area and estimation of reoccurrence in case of another strong earthquake. Rudarsko-geološko-naftni zbornik 19:111-120, 2007.

[8] Ž. Veinović, P. Kvasnička, V. Jurak. Geohazard characteristics of the Sava river plain near Zagreb. Konferencija razvitak Zagreba 2008. Acessed 15.9.2016.

[9] I. Idriss, R. Boulanger. Semi-empirical procedures for evaluating liquefaction potential during earthquakes. Soil Dynamics and Earthquake Engineering 26(2):115130, 2006. 11th International Conference on Soil Dynamics and Earthquake Engineering (ICSDEE): Part II, DOI:https://doi.org/10.1016/j.soildyn.2004.11.023

[10] D. Aleksovski, G. Mirakovski, D. Dojčinovski, et al. HE Brežice Geofizikalne raziskave in seizmična mikrorajonizacija,. Geofizikalne raziskave in seizmična mikrorajonizacija, IZIIS univerze Sv. Kiril I Metodij, Skopje., 2008.

[11] ARSO, Slovenian Environment Agency. Agencija republike slovenie za okolje.

[12] H. Tsuchida. Prediction and counter measure against the liquefaction in sand deposits. In Abstract of the Seminar in the Port and Harbor Research Institute, pp. 3.1-3.33. Ministry of Transport, 1970. 
[13] K. Ishihara, J. Troncoso, Y. Kawase, Y. Takahashi. Cyclic strength characteristics of tailings materials. Soils and Foundations 20(4):127-142, 1980. DOI:10.3208/sandf1972.20.4_127.

[14] H. B. Seed, I. M. Idriss. Simplified procedure for evaluating soil liquefaction potential. Journal of the Geotechnical Engineering Division 97(9):1249-1273, 1971.

[15] H. B. Seed, I. M. Idriss, F. Makdisi, B. N. Representation of irregular stress time histories by equivalent uniform stress series in liquefaction analysis. Earthquake Engineering Research Center, College of Engingeering, University of California, 1975.

[16] T. L. Youd, S. K. Noble. Liquefaction criteria based on statistical and probabilistic analyses p. 201-215, 1997.

[17] R. D. Andrus, K. H. Stokoe. Liquefaction resistance of soils from shear-wave velocity. Journal of Geotechnical and Geoenvironmental Engineering 126(11):1015-1025, 2000. DOI:10.1061/(ASCE)1090-0241(2000)126:11(1015)

[18] S. L. Kramer. Geotechnical Earthquake Engineering. Prentice-Hall International Series in Civil Engineering and Engineering Mechanics. Upper Saddle River, New Jersey., 1996.

[19] IRGO. He Brežice, Poročilo o impulznem globinskem zgoščevanju na testnih poljih. Faza: PGD. Report Nr. ic161/11. Ljubljana, Slovenia., 2011.

[20] V. Vukadin. The improvement of the loosely deposited sands and silts with the rapid Impact Compaction technique on Brežice test sites. Engineering Geology 160(Supplement C):69-80, 2013. DOI:https://doi.org/10.1016/j.enggeo.2013.03.025

[21] P. K. Robertson. CPT-DMT Correlations. Journal of geotechnical and geoenvironmental engineering 135(11):1762-1771, 2009. DOI:10.1061/(ASCE)GT.1943-5606.0000119

[22] S. Marchetti. In situ tests by flat dilatometer. Journal of the geotechnical engineering division 106(3):299-321, 1980.

[23] J. M. O. Hughes, P. K. Robertson. Full-displacement pressuremeter testing in sand. Canadian Geotechnical Journal 22(3):298-307, 1985. DOI:10.1139/t85-043

[24] R. Dobry, M. Vucetic. State of the art report: Dynamic properties and seismic response of soft clay deposits. In Proceedings of the Intl. Symposium on Geotechnical Eng. of soft soils, vol. 2, pp. 51-87. Mexico City, 1987.
[25] B. Hardin, V. P. Drnevich. Shear modulus and damping in soils: Design equations and curves 98:667-692, 1972.

[26] J. H. Schmertmann. Comparing DMT with CPT in NC/OC Sand Bucket test. DMT Digest (4), 1984.

[27] M. Lee, S. Choi, M. Kim, W. Lee. Effect of stress history on CPT and DMT results in sand. Engineering geology 117(3-4):259-265, 2011. DOI:10.1016/j.enggeo.2010.11.005.

[28] C. MacRobert, D. Kalumba, P. Beales. Correlating standard penetration test and dynamic probe super heavy penetration resistance values in sandy soils. Journal of the South African Institution of Civil Engineering 53(1):46-54, 2011.

[29] D. Adam, I. Paulmichl. Rapid impact compactor - an innovative dynamic compacttion device for soil improvement. In Proc. 8th International Geotechnical Conference, pp. 183-192. Slovak University of Technology, Bratislava, 2007.

[30] J. Kozeny. Über kapillare Leitung des Wassers im Boden, 136 (2a). Hölder-Pichler-Tempsky, A.-G. Akad. d. Wiss., Wien., 1927.

[31] P. C. Carman. The determination of the specific surface of powders. Journal of the Society of Chemical Industry 57:225-238, 1938.

[32] P. C. Carman. Flow of gases through porous media. New York: Academic Press, 1956.

[33] R. Chapuis, M. Aubertin. Predicting the coefficient of permeability of soils using the Kozeny-Carman equation. École polytechnique de Montréal 2003.

[34] W. D. Carrier. Goodbye, Hazen; Hello, Kozeny-Carman. Journal of Geotechnical and Geoenvironmental Engineering 129(11):1054-1056, 2003. DOI:10.1061/(ASCE)1090-0241(2003)129:11(1054).

[35] R. Chapuis, P. P. Légaré. A simple method for determining the surface area of fine aggregates and fillers in bituminous mixtures. Effects of Aggregates and Mineral Fillers on Asphalt Mixture Performance pp. 177-177-10, 1992. DOI:10.1520/STP24217S.

[36] I. Vaníček. Sustainable construction. Ed. 1st. Czech Technical University in Prague, Prague, 2011. 